\title{
The EC/EU between the Art of Forgetting and the Palimpsest of Empire
}

\author{
PATRICK PASTURE \\ Catholic University of Leuven/KU Leuven, Blijde Inkomststraat 21, 3000 Leuven, \\ Belgium. Email: patrick.pasture@kuleuven.be
}

The history of European integration is usually presented as both a peace project and an economic endeavour. What is largely ignored is that it also had a colonial dimension. This article first recalls this largely forgotten history, asking why and how it could be erased from memory. It then explores ways in which the EU and its predecessors constituted a new postcolonial identity and how colonial legacies somehow reappear in policies and representations.

Europe's colonial past is not merely an epoch of overseas power that is now decisively over. It is the beginning of an irreversible global transformation that remains an intrinsic part of 'European experience,' and is part of the reason that Europe has become what it is today. It is not possible for Europe to be represented without evoking this history and the way in which its active power has continually constructed its own exclusive boundary - and transgressed it. ${ }^{1}$

The traditional view on the history of European integration as the result of some sort of post-war enlightenment has been abandoned for quite some time now. The most recent shift in interpretation is the recognition of the EU's imperial and colonial antecedents. Fear of losing Europe's dominating position in the world has been a powerful motive to plead for a European federation of some sort since around 1900 . This fear was not only motivated by the competition from the USA, but also by the possibility of a 'reawakening' of the great Asian empires. After the Second World War these fears materialized, and now the loss functioned as a motive to unite. ${ }^{2}$

In a real 'Milwardian' reversal of the perspective, Peo Hansen and Stefan Jonsson demonstrated that post-war projects for European unity also aimed at 'rescuing' European colonial empires and that, in particular, the European Economic Community (EEC) had a colonial agenda. ${ }^{3}$ Their powerful argumentation refutes the view that European integration developed as an alternative to European imperialism and colonialism, as sometimes has been argued. ${ }^{4}$ Complementing the perspective of Hansen and Jonsson, as well as myself in earlier publications, in this article I will 
concentrate on the colonial legacies in the European project, including the question of how the colonial dimension could so easily have been forgotten. This amnesia, however, raises multiple issues with regard to Europe's self-representation and postcolonial identity, and ultimately also for the EU as an international actor today. In the 1960s and 1970s, the European Community (EC) (until 1967, European Communities), the predecessor of the European Union (EU, established in 1992), shook off its colonial legacy and reinvented a new identity based on universal values deeply rooted in European history. From this transition the EU emerged as a "normative power' defending these universal values at the international scene. But Europe's colonial history is like a palimpsest in which the 'after-image' of empire nevertheless shines through, which can effectively be seen in some EU practices up to today.

\section{The EC, a Colonial Empire?}

The remaining European colonial empires after the Second World War were all but ready to acknowledge the new postcolonial realities. In fact, the opposite turned out to be true, for the main powers concerned were taken by a renewed colonial fervour. ${ }^{5}$ After the loss of Asia, they looked for ways to maintain their colonial possessions in Africa, although they (some more than others) were aware of the mounting pressures against colonialism throughout the world, not the least in the US and the UN. ${ }^{6}$ The UK developed the British Commonwealth, officially constituted in 1949, as a means to associate former colonies to the metropole, but not all countries joined. Although Britain initially tried to firmly retain these under its control, the Commonwealth turned into an association of free states with a common link to Britain. Its objectives, at least in British eyes, moved from maintaining imperial dominance over enhancing British international status and prestige to preventing communist influence. Developing economic relations and cherishing a nostalgic image of 'Britishness' became the main perspective after the African countries gained independence. ${ }^{7}$ France after the Second World War continued keeping sovereignty over its overseas territories but created the Union Française to replace the colonial empire in 1949, giving citizenship to all its inhabitants. Although no longer called indigènes (indigenes) and entitled to political representation, the colonial peoples nevertheless did not enjoy the same (political) rights as the metropolitan French - a rather extreme case of some being more equal than others. ${ }^{8}$ Unsurprisingly, the Union Française was not particularly successful, neither politically nor economically. Hence, France imagined an ingenuous construction to share the burden of its colonies by associating them in a larger European project. With hindsight, this appears as a still-born attempt to continue what was already lost, but this was not obvious at the time.

The eclipse of Europe's dominance was widely lamented and ascribed to the many divisions of the continent, devastating economic and political competition, and the evil power of nationalism in general, which had resulted in two annihilating world wars (in Britain, however, nationalism was rather seen as what had saved it). The 
solution, so it seemed, was European unity - somehow ignoring that it had been European states that had conquered and ruled three quarters of the world. ${ }^{9}$

The global criticism of the country's policy in the Dutch East Indies in the immediate Second World War period motivated some in the Netherlands to turn for support to other European countries to resist what they considered the 'unfair' treatment by the UN of 'legitimate' Dutch colonial policy. ${ }^{10}$ They would soon though consider a European federation as a means to continue to play a major role in international politics, which also became a powerful motive for other countries when they realized that their power in the new order had considerably weakened. For France in particular, a European union offered a way to modernize its economy not only for domestic reasons, as A.S. Milward has emphasized, but to maintain its colonial empire. ${ }^{11}$ In fact, also in the UK, the colonial lobby upheld a similar reasoning: Foreign Secretary and Europhile Ernest Bevin even argued for FrenchBritish collaboration with regard to the development of Africa, but the French were wary of such an alliance. PM Clement Attlee preferred the Commonwealth over an association with the weak French. But although the UK gave up its empire in South and South-East Asia, it did not envisage the same for its Central African colonies until after the Suez crisis, at least not in the short term. ${ }^{12}$ Belgium initially was reluctant to engage in a European federation that included African possessions, as it feared foreign interference in its colonial policy, but also because it could not imagine, before 1960, that its crown jewel could ever become independent in any foreseeable future - by keeping the Congo underdeveloped it had also prevented any strong opposition from emerging. ${ }^{13}$

These post-war dynamics resulted in the formation of Eurafrica, an idea already suggested by Victor Hugo in 1879 and popular in the late 1920 s and $1930 .{ }^{14} \mathrm{~A}$ first attempt to create a Eurafrican association in the Council of Europe $(\mathrm{CoE})$ failed, although the Consultative Assembly in 1952 adopted the Strasbourg Plan, which aimed at improving economic relations with the overseas territories of European empires. The council of ministers, however, vetoed it. ${ }^{15}$ The Organization for European Economic Co-operation (OEEC) also included a Eurafrican perspective, which mainly implied that - contrary to the American objectives - Marshal funds could be used to sustain colonial policies. ${ }^{16}$ In the European Coal and Steel Community (ECSC), the idea of an association with the overseas territories was not retained although the possibility of a Eurafrican association was not ruled out. ${ }^{17}$ The question, however, re-emerged in blueprints for more effective forms of European association, such as the (failed) European Political Community (EPC) and, particularly, the Common Market.

Surprisingly, the arguments for the establishment of Eurafrica in the 1950s were virtually the same as in the 1920s and 1930s. Such an association guaranteed Europe access to African spaces for its population, raw materials for its industries, and markets for its finished products, in exchange for 'development', which mainly referred to technical infrastructure, which would facilitate the continent's economic exploitation. The demographic factor, while not entirely identical to the German demand for Lebensraum, gained a new dimension after Alfred Sauvy's publication of 
L'Europe et sa population in 1953, in which the French demographer suggested (inter alia) that Europe should offer 'development' in exchange for African 'space'. ${ }^{18}$ The emphasis on development corresponded to the rhetoric of the colonial civilizing mission, but in the 1950s was formulated more in terms of modernization and arguably aimed rather at placating both anti-colonial and American critics. For the US in contrast, development encompassed technical, economic and political measures aimed at stimulating a free world market and generating support for a liberalcapitalist model. In this respect, development prepared for self-determination or independence, which constituted core aspects of the American global anti-communist struggle after the Second World War. ${ }^{19}$ The Europeans however were more ambiguous. The Union of European Federalists UEF for example, in its Draft of a Federal Pact presented at the Conference of The Hague in 1948, observed that 'the era of national ownership of colonial territories is past. [...] From now onwards a common European policy of development for certain regions of Africa should be taken in hand'. ${ }^{20}$ However, the French Prime Minister, Paul Reynaud, pulled no punches stating:

We must also, if a free Europe is to be made viable, jointly exploit the riches of the African continent, and try to find there those raw materials which we are getting from the dollar area, and for which we are unable to pay. ${ }^{21}$

The dollar gap was indeed a major factor in the immediate post-war years. European political leaders actually opposed self-determination and used the rhetoric of development and the Cold War to maintain a colonial or, after 1960, neo-colonial relationship with the so-called 'third world'. The US did not push its European allies much. $^{22}$

The formation of Eurafrica was especially motivated by the will of maintaining a strong position in Africa - to keep 'Africa for Europeans' in the terms of the time (as in the 1920s and 1930s) - and of constructing a European power alongside the Soviet Bloc and the US. Especially for the French, the main advocates of Eurafrica, the purpose was indeed not only to prevent Africa from becoming communist, but also to keep US involvement to a minimum - certainly after the 'betrayal' of Suez - and to avoid that Europe, in the terms of the German Chancellor, Konrad Adenauer, 'would become crushed between the people of Africa and Asia if these nations should take a hostile attitude towards Europe'. ${ }^{23}$ A few Germans, however, prioritized the concept of development as a form of Widergutmachung after decolonization. ${ }^{24}$

Development became a key component of British, to a lesser extent than the French and the Belgian, imperial policy. Europeans emphasized charity, technical aid and infrastructure but far less, if at all, civic education. It is in this perspective that one has to interpret the phrase of the Schuman Declaration that 'with increased resources Europe will be able to pursue the achievement of one of its essential tasks, namely, the development of the African continent', although how was not further made concrete. $^{25}$ The project for the EPC foresaw the association of the European overseas territories, but it failed. Eurafrica then became a cornerstone of the Rome negotiations. France presented the association as essential from a geopolitical perspective, to 
avoid Africa succumbing to communist sirens, and beneficial for all partners - for the colonial empires interested certainly, but also for the other European member-states and for Africa itself. With the creation of a European development fund, its proponents hoped that member-states without colonial possessions would contribute to the project, as they too would benefit from the enlarged Euro-African market and access to African resources, in particular raw materials such as uranium. ${ }^{26}$ Britain incidentally looked at this ingenious suggestion with envy and it certainly contributed to making the British government move towards an affiliation with the EEC - which France particularly dreaded. ${ }^{27}$ Hence, a subtle game of attraction and competition developed between the Commonwealth, France and the Union Française, and the nascent EC. ${ }^{28}$ But non-colonial states remained less enthusiastic and while faced with the French sine qua non they agreed with an association, they did not accept anything more than a loose association with limited financial repercussions. ${ }^{29}$

Proponents of the association were careful in their use of words and avoided any explicit 'colonial' terminology. The Austrian publicist Anton Zischka showed one way, by emphasizing the 'technocratic' approach as an alternative for grand ideological projects, an approach that certainly appealed to the functionalist architects of a European union such as Jean Monnet. ${ }^{30}$ Others presented Eurafrica as an alternative for either national independence or empire. European Socialists in particular, subjected to anticolonial critiques from within their movements, considered Eurafrica as a federal project since the early 1950s. The French socialist leader and PM Guy Mollet defended this alternative view in a booklet published in 1958, Bilan et perspectives socialistes, in which he pleaded 'to allow dependent peoples to skip the stage of nationalism' (emphasis in the original). In his view, the world moved in the direction of greater unity instead of nationalism. Hence, Mollet advocated a federal structure which would limit the sovereignty of both the French and Algerians. This would take the wind out of the sails of anticolonial agitation - and hence save Algeria for France. ${ }^{31}$ While this argumentation could help persuade European federalists, ${ }^{32}$ it also appealed to African leaders who were looking for alternatives to empire but were not necessarily thrilled by the prospect of creating a European-style national state or just feared that independence would only lead to poverty and dependence in other guises. $^{33}$

The Treaty of Rome itself illustrates the case, as it spoke in evasive and embellishing terms about 'the solidarity which binds Europe and overseas countries'. Referring to 'the principles of the Charter of the United Nations' the text specifies that

The purpose of this association shall be to promote the economic and social development of the countries and territories and to establish close economic relations between them and the Community as a whole (...) [which] shall in the first place permit the furthering of the interests and prosperity of the inhabitants of these countries and territories in such a manner as to lead them to the economic, social and cultural development which they expect. ${ }^{34}$

The reference to the UN actually was a way of appeasing international anti-colonial protest. Leading politicians, including the German chancellor, Konrad Adenauer, vehemently denied that Eurafrica expressed colonial ambitions. ${ }^{35}$ But nothing in the 
plans suggested a roadmap to self-determination or independence. As Frederik Cooper concluded with regard to European colonial policies in the 1950s, while 'development was part of a wider policy by which colonial regimes sought to give modernizing elites - not just pseudo-traditionalist leaders - a stake in the changing imperial regime', the result was merely 'a kind of second-order citizenship derivative from the nationality accorded by a Dominion' in the British case and very limited colonial representation in the French one (and none of these in the Belgian case). ${ }^{36}$ While aiming at 'increasing trade and to pursuing jointly their effort towards economic and social development' (art. 3) the EEC would indeed retain Africans as dependent on European patronage: the aid envisaged was essentially to build a market for European products and the exploitation of raw materials and human resources, not a sort of 'emancipation' and liberation. So if according to Dutch Foreign Minister, Joseph Luns, in his speech delivered on the occasion of the signing of the Rome Treaty, 'These treaties that abolish the barriers between our countries [...], will in our firm conviction create the conditions for continued economic growth for our old continent and allow the continuation of its greatest mission of world civilization', it may be clear that this 'greatest mission of world civilization' was not meant to be completed soon. ${ }^{37}$ It was also an outspoken paternalistic one, as in contrast to what had been foreseen in the Strasbourg Plan and the EPC project, there was even no mention of the representation of Africans, in whatever capacity, in the decision-making bodies of the EEC or the European Development Fund. ${ }^{38}$ The rhetoric actually followed the model of the civilizing mission that had legitimized European colonialism. ${ }^{39}$ Hence, Eurafrica was conceived as a pure-sang colonial enterprise, not a neo-colonial (or post-colonial) one, ${ }^{40}$ even if the African territories were only 'associated' and not fully included in the EEC (apart from Algeria, which, albeit with a lot of conditions, was an integral part of France).

The project of Eurafrica confronted African leaders with difficult choices. It particularly challenged ideas about African unity, on which they were already divided. Although the project also counted some important supporters - most notably Félix Houphouët-Boigny of Ivory Coast - many Africans viewed the project with much suspicion. Particularly in French Africa, many preferred the Union Française, in which they were granted citizenship (albeit not with the same rights as metropolitan French!). They feared that Eurafrica would constitute a regression compared with the Union, also because Eurafrica would mean that Italians, Belgians and Germans - all viewed worse than French - would become involved. Others, such as Sekou Touré, Kwame Nkrumah and Frantz Fanon, privileged a Panafrican union and saw in the Eurafrican project a means to keep Africa divided and subordinate to European interests. Many African leaders though, such as Leopold Senghor, Habib Bourgiba and Félix Houphouët-Boigny - all future presidents of their respective countries after independence (Senegal, Tunisia and Ivory Coast respectively) - nevertheless eventually went a long way to give Eurafrica a chance, hoping to establish a relationship of equality, even if they also expressed reservations and remained cautious. They reckoned - or rather hoped, as especially Senghor had reservations as well - that Europe would contribute to the development of their countries. Basically, they shared 
the western discourse on modernization: faced with a difficult and painful 'choice' between Africa and Europe, they - as Frantz Fanon described it $^{41}$ - chose the latter; some even 'understood' the European 'need for space' in Africa. Notwithstanding their anticolonial stance, they had been socialized in western thinking. ${ }^{42}$

The quite explicit colonial dimension of the post-war EC quickly vanished with the independence of most African countries in the early 1960s. Little still recalls this period, except for some vestiges of colonial territories such as Ceuta and Melilla in North Africa.

\section{Colonial Amnesia or the Advantages of Forgetting}

That so few associate Europe and in particular the European institutions with this colonial past is worthy of some deeper reflection. Although at the time the connection was obvious, Eurafrica soon disappeared from the major narratives of European integration. The major textbooks of European integration remain entirely silent on the issue, as do museums and exhibitions. ${ }^{43}$ The House of European History in Brussels includes a small section on Europe's colonial past, but disconnects it from the following narrative on the formation of the EU. How is that possible? The answer is not as easy as may seem at first sight.

Perhaps we should distinguish between EU institutional amnesia and that by the different European colonial empires involved - the UK, France, Belgium and Italy in the first place. ${ }^{44}$ Our focus in this article is on the former, although colonial memories of European countries and of the EC/EU cannot be completely dissociated as a (unforeseen) consequence of what Kiran Patel identified as the synecdochic character of EC/EU discourse. ${ }^{45}$ If the EC/EU speaks for an abstract 'Europe', then of course national European memories - and amnesias - are also those of the EC/EU. At first sight the reverse is not necessarily the case.

With regard to the national colonial memories we should first observe how diverse they actually are, even if there are also parallels and they are to a certain extent 'entangled'. ${ }^{46}$ No doubt the British view their imperial past quite differently from the French, while imperial 'competition' sometimes seems continued in the historical representation of colonization, as between Belgian and British. The Irish and Poles incidentally share some recollections of being colonized rather than being colonizers themselves. But such diversities also exist with regard to other issues, which has not prevented the EU from establishing a common historical narrative. ${ }^{47}$ This is in itself noteworthy and illustrates how the historical representation of the EU cannot be dissociated from national memories. However, the experience with trying to create such a narrative out of diverse perceptions of the past after 1989 does reveal the limits of the endeavour as well. It is also noteworthy that many historical studies on European memories that explicitly discuss the diversity of remembering, ignore colonial memories, and the one that does not - Claus Leggewie's landmark essay Der Kampf um die europäische Erinnerung - effectively 'nationalizes' it. ${ }^{48}$

As regards the self-definition and representation of Europe and the European institutions, initially the Council of Europe $(\mathrm{CoE})$ had the competence and the 
instruments to develop a proper historical narrative about itself, but it is the EC that really did so, albeit only slowly from the 1970s onwards; it, however, obtained cultural competence only with the Maastricht Treaty in 1992, establishing the EU. ${ }^{49}$ However, what can be easily concluded is that in the historical self-representation, also of the $\mathrm{CoE}$, the colonial-imperial perspective is entirely missing.

Ole Wæver argued that Europe constructed a post-war identity mainly by othering its past, which was often - although not exclusively - associated with war and destruction, and focused on the antagonism between France and Germany. ${ }^{50}$ Colonization, however, did not belong to this narrative. ${ }^{51}$ In fact, after 1945 a new narrative emerged that was particularly comforting, self-congratulatory and allowed one to focus on the future instead of the past. It emphasized freedom and human rights (an issue to which I will return in the next paragraph). These got a particular significance through the Cold War, which until 1989 seemed to have eclipsed other narratives - the gradual recognition of the history of Eurafrica by historians and social scientists since the 1990s can be viewed as a confirmation of this hypothesis, although in my view the Cold War is overstated compared with decolonization and the emergence of the Third World. ${ }^{52}$ The growing impact of the Third World turned the colonial heritage into an embarrassment, all the more so as it contradicted the new narrative, which made the need for forgetting even more compelling. The Cold War, the emergence of the Third World as a political actor, and the self-comforting selfimage in fact all demonstrate the 'imperative of the present' which underpins most historiography on European integration up to the 2000s. Many historians, especially in the crucial 1970s, shared the same federalist beliefs and presentist mode as the European institutions that, moreover, often supported them with funds and infrastructures, and wrote histories of European integration that corresponded to the ideals and narratives of the EC/EU itself. ${ }^{53}$

At this point one might suggest that this forgetting may be a natural reaction after a traumatic experience. Decolonization may have been traumatic, which in itself would explain processes of amnesia, suppressed memories and an unresolved past still in need of finding a way to settle. ${ }^{54}$ Post-war reconciliation in (western) Europe also implied 'forgetting and forgiving': it took some 20 years until the most painful memories softened and a more active healing process of remembrance could be pursued in which the atrocities of the war became central so that the past for Europe was not 'allowed to become its future' (Ole Wæver). ${ }^{55}$ This, however, implied an active process of remembering and handling, a process well studied with regard to the German handling of its Nazi past. Slowly, such a process has been initiated with regard to the colonial past of national states as well, although by no means complete and without conflicts, as the (in)famous zwarte pieten-discussion in the Netherlands illustrates. ${ }^{56}$ However, there is no such thing with regard to the EU's colonial history. It, for example, would require a conscious recognition, if not of guilt then at least of the fact that wrongdoings happened. It is hard to sustain that the EC/EU recognized any guilt or fault at any point since the 1960s.

Another reason why colonial empires - in this respect one could include the EC/ EU - preferred to forget was of course that decolonization implied loss and defeat. ${ }^{57}$ 
And if completely forgetting is not entirely possible, former colonial states usually display a recollection of colonization that is, to put it mildly, overly benign, as if it had been all an 'inherently benevolent' enterprise, 'for the good of the people'. ${ }^{58}$ This benevolent view actually aptly applies to the EC/EU, as is apparent in the hesitation to call Eurafrica 'colonial' and the somewhat clumsy attempts to erase the colonial past from European integration history. ${ }^{59}$ However, forgetting is not innocent. The German historian Lucian Hölscher contends that it can be interpreted as an act of denying solidarity - almost a damnatio memoriae. ${ }^{60}$ In this respect one may note that by effectively dissociating itself from the colonial past, the EC/EU also escaped from the 'ethical imperative' that accompanies such a recognition - and from associated demands for excuses and reparations. ${ }^{61}$

Forgetting hence easily amounts to denial. However, Europe sometimes presents the next step in this historical 'reconstruction' - in fact, a $180^{\circ}$ reversal of the real impact of colonization - which in France was made in the final days of the Algerian war of liberation. It basically consists of integrating decolonization into a framework of modernization and progress that, evidently, finds its origin in Europe: 'decolonization now appeared as wholly consistent with a narrative of progress - the ongoing extension of national self-determination and its corollary values: liberty, fraternity, equality, and the Rights of Man - that began with the French revolution', Ton Shepard observes in his acclaimed The Invention of Decolonization (2008). ${ }^{62}$ It was a discourse that, paradoxically, could also appeal to the colonized, as it offered a prospect for restating themselves in a future-oriented narrative of progress and modernization. I will return to this observation below.

In any case, the colonial amnesia allowed the EC to construct an untarnished alternative narrative. But again such an explanation is only partially valid, as European states - ex-colonial empires - and the EC had to continue cooperating with former colonies. Memories hence were, as Jan Jansen contends, 'deterritorialized', something the EC could do even more easily than the metropoles. ${ }^{63}$ In this respect the national issue was important, but in a different respect. Indeed, as the EC washed its hands of colonial history, decolonization became entirely a national matter. The now ex-colonial empires did not object. On the contrary: France continued to view Africa as its symbolic territory, as came to the fore in its development policy, resulting in recurrent tensions with the EC Directorate-General for Development (DG VIII). That Eurafrica remained strongly connected with French colonial ambitions may have helped in a different respect: its failure could hence easily be put on the latter's back. Eurafrica in contrast appeared as a technical affair of high politics and administration. It hence shared the fate of the European institutions in general, of being neglected and little loved, which made forgetting it all the easier. ${ }^{64}$ All this surely facilitated the EC to dissociate from the colonial enterprise, all the more so as a new narrative was readily available.

There are many reasons why the EC/EU may not be too keen to remember or even to recognize its colonial past, but in this case I wonder whether the collaboration of the colonized/postcolonial nations was not necessary too. The colonized are as much prime actors as the colonizers, pursuing their own agenda. ${ }^{65}$ During the time of the 
signing of the Rome Treaties and the construction of Eurafrica, anticolonial leaders were divided. Some, among which most prominently Kwame Nkrumah of Ghana, virulently opposed Eurafrica, launching a worldwide campaign, among other places in the UN, to denounce the colonial policies of the EC. Others though, such as Leopold Senghor, gave the initiative a fair chance and actually used a language of reconciliation, which implied a way of 'forgetting' the colonial past. After decolonization, this line prevailed as Eurafrica blended seamlessly into the new development action of the EC and continued in the Yaounde Convention (1963). ${ }^{66}$ Although there remained a strong opposition, with Nkrumah again in a prime role defending the Pan-African ideal, most African leaders rather opted for an association with the EC. Even the African members of the British Commonwealth, which initially radically opposed the idea, increasingly considered the association as a model to follow. ${ }^{67}$

In this context, emphasizing the colonial antecedents could be very counterproductive for the African leaders. It surely was in their advantage to look ahead instead of backwards. Moreover, European politicians as well as the administration of DG VIII and the European Development Fund actively promoted their development activities. The administration of DG VIII entertained a close relationship with the first generation of African leaders, who found themselves strengthened by this arrangement, as it continued to give them access to European markets - staying out would imply losing them - and aid. ${ }^{68}$ This adds another dimension to Hansen and Jonsson's astute image of the EC/EU as a 'vanishing mediator': this collaboration allowed diverting the memory of colonization. ${ }^{69}$ Moreover, insofar as decolonization could be framed within the discourse of progress and modernization, it was appealing, especially for activists who, as I mentioned earlier, by their education and schooling were moulded in the modernist mind. The European amnesia hence may be, at least in part, African as well.

To be sure, the EC/EU was not an empire, which is a kind of state, as it emphatically lacked any instruments of power and expansion, in particular an army (which

does not mean that is was entirely powerless though). ${ }^{70}$ This too, in my view, may help to explain why so many African leaders were willing to take the chance and why this colonial heritage was so easily forgotten afterwards. There still is, however, a very different dimension, one that I have not discussed yet: that, for the contemporaries, Europe represented not only colonialism and oppression, but also the promise of a better life, in all respects, and of equality and justice. This constituted a possible keystone to construct a new identity, as we explore in the next part of this assessment. However, that was far less evident than might appear in today's complacent European self-perception.

\section{Building a Post-colonial Identity: Difficult Transitions}

If the EC is not remembered as a colonial enterprise, it is also because it embodied a quite different narrative of peace, democracy, economic progress, development, human rights and the rule of law, which not only appealed to themselves but to others as well - even if they had been confronted with the opposite of these values in practice. 
Each of these values, however, raises serious questions. The view of the EC/EU as a harbinger of democracy, for example, clashes with the nature of the European Communities, which were created as technocratic policy bodies with the hardly hidden purpose of avoiding democratic control - hence the difficulty of generating legitimation and of introducing a representative system in the 1990s. ${ }^{71}$

The message of peace was without doubt the most persuasive, although well into the 1960s it actually mainly referred to the European lands themselves (with uncertain and ambiguous boundaries to the east), excluding overseas territories. The 2012 Nobel Peace Prize formulated it just right when it gave its award to the EU because it 'and its forerunners have for over six decades contributed to the advancement of peace and reconciliation, democracy and human rights in Europe' (emphasis added). ${ }^{72}$ Colonial wars were obviously waged by European empires, but they were neither perceived as 'European' matters nor associated with the EC, not with hindsight but not in contemporary sources either. The European project hence was essentially viewed as inner-European, even if, as I argue above, it cannot be dissociated from colonial-imperial goals and many plans about European unity extended far beyond the traditional geographic concept. ${ }^{73}$

Although it still took years to fully materialize, once the colonial era was left behind, the EC/EU could fully focus on a discourse of 'universal' values that would become the cornerstone of its foreign policy: with hindsight it seems a 'liberation' in its own right. It actually offered a platform for the member states to shake off their colonial pasts, trading the past in for a new and potentially very effective alternative narrative. Europeanization hence allowed, in the astute words of David Allen, the 'European Rescue of National Foreign Policy'. ${ }^{74}$ This was, however, not a foregone conclusion.

Although the EC also ascribed itself a role as peace-broker, including at world level, I will in the following focus on two other features of this self-representation: the importance of human rights and of development.

\section{The European Invention of Human Rights}

One 'traditional' pillar of European identity refers to human rights and the rule of law. In contrast to the popular image that seeks the origins of human rights in the European humanist and Enlightened tradition, Samuel Moyn's ground-breaking history of human rights The Last Utopia rather argues that they 'emerged seemingly from nowhere and overnight' only in the $1970 \mathrm{~s} .{ }^{75}$ That certainly is an overstatement: Europe has a long history of referring to humanitarian principles and the rule of law in both domestic and international politics. ${ }^{76}$ However, as Moyn convincingly demonstrates, what was presented as human rights was closely associated with the emerging notions of citizenship and the nation-state - as the French Declaration stated, they were 'rights of man and the citizen', a significant qualification which was only reinforced in the following century and a half. Hence, these so-called 'universal human rights' in practice only benefited European interests and applied only to Europeans: they, for example, legitimized military interventions in non-European 
countries to 'protect' Christians and, in particular, missionaries, but never the reverse. Nevertheless, the idea of universal rights had been formulated, albeit rather by Haitian slave revolutionaries than by their French counterparts. European discourses about equality and human dignity were at various times picked up by anticolonial militants in Asia and Africa, who either endorsed these ideals, appealed to them in order to confront European colonizers and challenge them to live up to these ideals to fight Europeans on their own terrain - or, alternatively, to reject Europe's civilization of hypocrisy altogether. In the post-war debate on human rights, anticolonial militants played a major, although disputed, role: historians such as Samuel Moyn and Jan Eckel argue that anti-colonial militants did not refer to the concept of universal human rights, while others such as Fabian Klose and Roland Burke explicitly refer to the multiple uses and references to human rights. ${ }^{77}$ As regards Europe the question is even more complex.

Human rights were seen as building blocks of the new 'federal' Europe as it was imagined after the Second World War by European federalist politicians and jurists. Although the British government opposed this association between European federal idea(1)s and human rights, ${ }^{78}$ respect for 'individual freedom, political liberty and the rule of law' (note the absence of the term 'human rights') became membership conditions of the Brussels Treaty in 1948 as well as the Council of Europe (CoE). The latter, in December 1950, concluded the (European) Convention for the Protection of Human Rights and Fundamental Freedoms (ECHR). The establishment of a European Court of Human Rights (ECtHR) was already foreseen, although it would only materialize in 1959. From this early post-war time, human rights were formulated as constituent of a new European identity, demonstrating the ambition to break with the past. The ECHR is often represented as a 'quasi-revolutionary idea' as, in contrast to the Universal Declaration of Human Rights adopted by the UN in December 1948, it implied that it was binding (at least if ratified). ${ }^{79}$ In addition, detailed plans for a European Political Community (EPC) in 1952-1953 foresaw a strong role of the European institutions for promoting human rights. ${ }^{80}$ All these assessments, however, ignore the colonial dimension.

Still, the establishment of a human rights discourse was linked to colonization in at least two ways. First, the European (western) emphasis on individual human rights was not just connected to structural processes or a new recognition of the human person, as both Samuel Moyn and Hans Joas postulate, ${ }^{81}$ or to defend conservative interests - Marco Duranti's recent thought-provoking argument ${ }^{82}-$ but also implied a rejection of the plea for self-determination as demanded by anticolonial militants. ${ }^{83}$ Secondly, in contrast to the UDHR, the ECHR did not need to apply to the overseas territories and, if it did, its provisions could be suspended. Free elections certainly were not meant to apply to colonies. Although France liked to portray itself as a champion of human rights, it rejected any infringement on its sovereignty - it certainly did not take any risk to end up in the dock - and did not sign the Convention until 1974. ${ }^{84}$ The UK, the other main colonial empire, did so in 1952 and even extended it, 'generously' in its own understanding, to the overseas territories (albeit with exceptions), but it did not accept the clause on individual petition. 
Nevertheless, European colonialism was viewed as an 'embarrassment', in the understating term of Fabian Klose. ${ }^{85}$ In the CoE, most European and indeed African protagonists (in particular as representatives of the French overseas territories, part of the Union Française) were all too aware of the contradiction, and the opportunity for communist propaganda. ${ }^{86}$ The latter argument showed how the issue undermined the Cold War dichotomy between a 'free world' where human rights were supposed to be upheld and the communist sphere where they were suppressed. So, if the ambition to promote human rights was abandoned, it was not so much because Europe opted for a more functionalist approach, but rather because the mounting colonial tensions since the mid-1950s prevented European powers from emphasizing human rights, let alone to defend themselves against accusations of perpetrating abuses in their colonies. ${ }^{87}$ That is the main reason why the Rome Treaties carefully avoided any reference to human rights.

However, the acceptance in the 1960s (especially after Algeria's independence in 1964) that the days of empire and colonization were gone, changed everything. It opened the way for the acceptance of the competence of the ECtHR - France signed the Convention in 1974, although it only accepted the right of individual petition in 1981. The Détente also opened space for a more critical approach in Europe. Even the European Court of Justice (ECJ), in blatant contrast to the 1950s and early 1960s, promoted human rights as it pursued an active policy of furthering European integration, using human rights as a major instrument to extend its authority in the emerging institutional framework. ${ }^{88}$ Albeit with some distance, the ECtHR could manifest itself as an important actor as well. ${ }^{89}$ Gradually, human rights emerged as a cornerstone of European identity and of its international politics. This came to the fore in 1962 when Franco's Spain applied for EC membership, and with the Greek colonel putsch, which provoked the withdrawal of Greece from the CoE in 1969. In the early 1970s the EC especially targeted relations with countries such as Portugal, Chile and South Africa - significant choices, as they allowed it to distance itself even more from its colonial past. Lorenzo Ferrari concludes that they aimed at presenting the EC 'as a supporter of the independence of the African peoples and of racial equality' ${ }^{90}$ Politically, human rights dominated during the Conferences on Security and Co-operation in Europe (CSCE) in Helsinki in 1973 and 1975, signalling the breakthrough of human rights in European and international politics. ${ }^{91}$

\section{The Metamorphosis of Development}

A similar story can be told with regard to development. As argued above, recognizing development as part of a postcolonial European identity was less evident than may appear at first sight: development for European colonial powers had not meant a road towards self-determination let alone independence, which would have required political formation alongside furthering economic, technical and social infrastructures. Still, it could be presented in an altruistic fashion, and perhaps more importantly as a 'generous' offer towards 'less-advantaged countries', which could put them on the way to economic success and prosperity, in their own interpretation on a par with Europe. That could make it sound attractive for Asians and, in particular, for Africans. 
Hence Eurafrica, although designed as a colonial enterprise, could easily be transformed into something different. Illustrative is the discourse used at the signing of the Yaounde Convention in 1963. While the convention actually confirmed the basic agreements of the Rome Treaty with respect to the association of the overseas territories, it was presented as a 'new start' for Eurafrican relations on the basis of a 'complete equality and friendly relationships', implying full recognition of sovereignty. A clear commitment to 'turn the page' was shared by all; the term Eurafrica was explicitly banned. Development would become the new 'mission for Europe'. Ironically though, development was phrased in roughly the same terms as in the 1950s and positioned Europeans again as the masters and teachers, confirming Africans in a subordinate position, with few instruments to impact upon the decision-making process. Moreover, aid went mainly to infrastructure, not to industrial development or political formation, mirroring colonial practices and ensuring the continuation of industrial inequality. ${ }^{92}$ African and, though less obvious, Asian countries after independence continued to be perceived as 'useful providers of labour and raw materials, potential outlets for surplus manufactures, junior partners to be preserved from the spread of international communism', as Giuliano Garavini recently summarized (albeit this was a sign of continuity rather than a new orientation as Garavini suggests). ${ }^{93}$ Moreover, the focus on development allowed dissociating development from human rights issues, which had several advantages: it further distanced the EC from its colonial past and allowed it to present its relations with Africa as between equals and reciprocal. Some Europeans remained ambiguous though: the Christian democrat Mario Pedini for example spoke of a 'natural relationship' between Europe and Africa, and implicitly referred to colonialism as 'a particular form of international organization where certain people - by their own authority - interpreted and organized the general well-being (welfare) also for other peoples' ${ }^{94}$ The denial of its colonial history implied that the EC reinforced the unequal relationship, refusing the deliverance of remembering. But, as we have seen, reactions in the former colonies were mixed - in some ways the idea that Yaoundé constituted a break with the colonial past prevailed. ${ }^{95}$

In the emerging new realities of 1960s' Europe advanced development as a source of identity and pride, through which Europe presented itself as an 'equal' partner with the Third World. Against critiques that it focused on just French and Belgian former colonies, aid was extended to other countries as well. All African countries, also those of the British Commonwealth, could join the Association, as was already granted in 1963. ${ }^{96}$ The Arusha agreement of 1968 with Tanzania, Uganda and Kenya - countries that belonged to the British Commonwealth - illustrated the desire to break with a past of competing imperial legacies. Development policies moreover were flanked by increasingly important trade policies: 'trade not aid' became the key concept in the 1960s and 1970s - although the principle of reciprocity that the EC demanded benefited the European member states considerably more than it did the Africans. But in the 1970s, culminating in the Lomé Convention of 1975, this was gradually changed to the benefit of the African countries. ${ }^{97}$

The change in policy was slow though. Many civil servants responsible for the EC development policies, among whom Commissioner Robert Lemaignen and his Head 
of Cabinet EDF director Jacques Ferrandi, had earned their spurs in the French and Belgian colonial administrations before. Their policies continued to focus on economic and technological cooperation, taking in account the 'realities' 'on the ground' and collaborating with the local leaders, as had been the case before 1960. In her pioneering study on the European development infrastructure Véronique Dimier hence labelled DG VIIII 'the last French colony', although she also recognizes the tensions between especially French and European perspectives. ${ }^{98}$ Essential in the discourse of DG VIII was the concept of 'altruism': the EEC 'generously' gave where others - the UN - gave loans. But of course this only illustrates the profoundly paternalistic attitude that still prevailed. ${ }^{99}$ Nevertheless, the EC administration took matters in its own hand and systematically raised the bar; it certainly played a key role in making development an important ingredient of EC policy. Very soon after the implementation of the EDF, tensions arose between the administration and national governments, which culminated in the Lomé Convention of 1975. Although often viewed as a revolutionary break in the relationship with the former colonies, as it included a firm commitment to an equal partnership and non-reciprocity with regard to the opening of markets to the advantage of the African, Caribbean and Pacific (ACP) countries that signed the convention, the actual trade relationships remained unequal and, in sum, largely to the advantage of the Europeans. ${ }^{100}$ Moreover, the decisions mainly reflected intergovernmental bargaining between the EC member states, in particular France and the United Kingdom. They had developed quite different relationships with their former colonies and in practice largely 'defended' the interests of their former 'empires', acting effectively as 'patrons' to their former colonies. ${ }^{101}$ This being said, one should not underestimate the impact of African leaders especially on European - at least French - national policies either. ${ }^{102}$

\section{Building a New Identity}

By the early 1970s the European Communities found themselves once again - and obviously not for the last time - facing an existential crisis. Although the enlargement of 1973, when the UK, Ireland and Denmark joined the EC, showed the latter's growing symbolic power, it certainly also demanded institutional and cultural adjustments proper to any merger operation, especially as some of the new members from the very beginning had different ideas about the nature of their alliance. Moreover, the European economy was slowing down, putting an end to the so-called 'golden sixties'. The first Oil Crisis of 1973 would effectively plunge Europe into a lasting economic depression. But the changed geopolitical context also caused concern. The US adopted a more unilateral course, while a certain détente between the superpowers opened up space for more autonomous European policies. ${ }^{103}$ Decolonization often seems underrated although it transformed the world profoundly, as the crisis in the Middle East demonstrated. Although the transition towards the new postcolonial realities happened surprisingly smoothly, at least after the main colonial battles were lost - the Congo in 1960 and Algeria in 1962 - the EC still had to reposition itself. It took more than a decade before the EC formulated a new vision 
about itself in the new world. The impetus to do so came both from within the European institutional realm - including the legal activism of both the ECJ and the ECtHR - and from outside, such as NGOs.

At an international conference of EC heads of states in 1972, combating underdevelopment was for the first time formulated as a foreign policy objective, which was further confirmed by the Copenhagen Declaration on European Identity in December 1973. It also stated as its ambition 'to safeguard the principles of representative democracy, of the rule of law, of social justice and of respect for human rights', explicitly aligning itself with the international community through the UN, which became a key element of EC international policy - a very significant evolution that merits a separate assessment. ${ }^{104}$ Nevertheless, the document displays a remarkable ambiguity entirely in line with the discourse in use since the Rome Treaties: it refers to the 'close ties' that European countries had developed 'with many other parts of the world'. Passing over a long tradition of imperial and colonial violence, it presents the EC as 'an assurance of progress and international equilibrium' (art. 5). The text euphemistically speaks of 'long-standing links' in the case of 'the Mediterranean and African countries'. The declaration mainly emphasizes the EC commitment to play an active international role - actually the text speaks of 'its proper role in the world' (emphasis added) - and ambition to develop an intense relationship with its former colonies, although any reference to the colonial and imperial nature of those relationships is carefully avoided. Although the international ambition is stated in terms of promoting justice, equality, prosperity and security, colonial hierarchy reappears in the unequal presentation of different regions and in the outspoken moral undertone, recalling the colonial 'civilizing mission'. The text is also interesting in that it emphasizes the unity of the communities on a 'civilizational' basis, again referring to an essentially colonial concept, very similar to the way human rights were promoted as a cornerstone of the new Europa after the Second World War, effectively underlining its superior position. ${ }^{105}$

The 1975 Tindemans Report on the future of the European Communities, named after its author, the Belgian Prime Minister Leo Tindemans, constituted another important moment in the search for a new identity and positioning of the EC in a postcolonial world order. It was based on the extensive consultation of politicians, institutions, pressure groups, academics and think tanks supposedly representing some sort of European public opinion. It focused on common identity politics and promoting social cohesion. ${ }^{106}$ Tindemans, however, realized that the relationship between the EC and what was now called the 'third world' constituted a major issue, which required reaffirming Europe's role in global politics. ${ }^{107}$ Although the Belgian PM downplayed the significance of colonial history (sharing the extremely complacent Belgian attitude towards its colonial past) and emphasized the need for a strong EC common policy as a global power, some of his interlocutors warned against 'imperialist' motives. ${ }^{108}$ The Netherlands criticized EC policies as neocolonial, targeting in particular the Lomé convention, and referred to a 'historical responsibility' of Europe towards the Third World - unaware it seems of the ambiguity of the idea, which however was widely shared at the time. ${ }^{109}$ The French 
socialist François Mitterrand, seemingly the only one who called a spade a spade and spoke about 'the world that had previously been colonized by force', considered EC policies explicitly neo-colonial, but he remained vague as regards an alternative. ${ }^{110}$ The French government, and the final text of the Tindemans report, rather believed in the economic 'take-off' of the Third World as a result of their control of raw materials, which was seen as an opportunity as well as a threat, both for the West and for many Third World countries - the report emphasized the former, but implicitly, as the discussions show, the latter was perceived as more acute. ${ }^{111}$ But 'luckily', as the President of the European Commission, FrançoisXavier Ortoli, declared in a speech at the European Parliament in February 1975, the EC was more apt to develop relationships with Africa 'because the European Communities in contrast to some member states were less contaminated by a colonial past' (emphasis added). ${ }^{112}$

By shaking off its colonial heritage, which implied its 'forgetting' and denial, the EC could redefine itself as an international actor promoting peace, development and human rights, albeit that these were not linked to one another before the late 1970s. ${ }^{113}$ The resistance to associating development and human rights, however, did not come from Europe, but rather from the African leaders. It is only in the 1980s and 1990s, in part because of severe human rights abuses by inter alia the Ugandan dictator Idi Amin, and the Rwandan genocide, that the perspective decisively shifted. Less focused on a strong corporate identity, the EC/EU needed to accommodate different sensibilities, hence it put greater emphasis on values and emphasized the idea of 'Unity in Diversity'. ${ }^{114}$ The single European Act of 1986 claimed to:

promote democracy on the basis of the fundamental rights recognized in the constitutions and laws of the Member States in the Convention for the Protection of Human Rights and Fundamental Freedoms and the European Social Charter, notably freedom, equality and social justice. ${ }^{115}$

The EU, established in 1993, continued this orientation and would really promote human rights as a key element in its international policy. ${ }^{116}$

Evaluating the extent to which the EU has succeeded goes far beyond the purpose of this article. As Karen Smith puts it, such an affirmation requires more than lofty words or even humanitarian policies:

Analysing the extent to which the European Union promotes human rights and democracy, and with which instruments, and how consistently, and how effectively, is not enough. We should look at the whole of the EU's impact on international relations and other states (whether deliberate or not), as well as what the EU is not doing, to promote justice, understood more widely than is usually the case - though we must debate what 'justice' should mean. ${ }^{117}$

Doing so goes well beyond this paper's ambition, but - to some extent - raising the question is already answering it. In the framework of this paper it suffices that the focus on Europe's civilizational discourse and amnesia with regard to its colonial past offers another take on this issue. 
The Coutounou Agreement of 1999 illustrates the difficulties and indeed the ambiguities of EU policies nicely: while proposing a broad package of reforms linking respect for human rights, economic reforms and the efficiency of aid, it clearly reveals the EU as a 'normative power' which sets the terms and manifests itself as a prime actor in international politics. ${ }^{118}$ Emily Jones and Clara Weinhardt even suggest a return of colonial practices happened since then with regard to the 'Global South', for example in reintroducing 'reciprocity' in trade relations similar to the French colonial policy of the 1950s: reciprocity in the case of unequal economic relations is quite detrimental for the weaker part. In addition, EU policies remain strikingly paternalistic. ${ }^{119}$

\section{Epilogue}

The EU quickly established itself as a peaceful and open society in which the rule of law reigns and human rights are respected. This inspired the EU not only to base its newfound identity and self-confidence on these principles, but to make them the cornerstone of its emerging external policies. Robert Kagan hence commented that 'the transmission of the European miracle to the rest of the world became Europe's new mission civilisatrice [...] Europeans have found a new mission born of their own discovery of perpetual peace'. ${ }^{120}$ François Duchêne, a high-level collaborator of Jean Monnet - also his biographer - and scholar of European integration, presented the (then) EC as a 'new stage of political civilization' because it acted not as an empire, but as a 'civilian power'. 121

Political scientists have pursued this idea mainly in the wake of Ian Manners' 'normative power' theory. ${ }^{122}$ Manners, at least in his earlier publications, ${ }^{123}$ argues that the EU constitutes a break with 'pre-existing political forms and that this particular difference predisposes it to act in a normative way', constituting a 'normative difference' which apparently sets it apart from both its own imperial (?) past and the rest of the world. ${ }^{124}$ Hence, when the then President of the European Commission, José Manuel Barroso, called the EU 'the first non-imperial empire' (10 July 2007), ${ }^{125}$ which provoked a storm of protest in the (mainly British) press, he was actually in complete agreement with mainstream political science. His words actually echo Jürgen Habermas who wrote that Europe got a 'second chance' to make an 'appearance on the world stage', although 'not on the terms of its old-style power politics but on the changed premises of a non-imperial process of reaching understanding with, and learning from, other cultures'. ${ }^{126}$ In this respect, Richard Rosecrance observed 'that it is perhaps a paradox to note that the continent which once ruled the world through the physical impositions of imperialism is now coming to set world standards in normative terms' ${ }^{127}$ The comment - besides grossly overstating the EU's impact on international politics - at least suggests the possibility of continuity: it is paradoxical only if one accepts the normative stance that the EU constitutes a radical departure from imperial policies. But the very fact that it adopts such a normative policy suggests that it is perhaps not that 'non-imperial' after all. 
I have already referred to normative power with regard to development. However, the 'normative power' approach has in particular been used to assess the EU's accession policy. Critical studies argue that the EU's accession policy displays the same structural characteristics of the old colonial 'civilizing mission', albeit perhaps without its inherent violence and legitimizing features ('soft imperialism', in the terms of Björn Hettne and Fredrik Söderbaum). ${ }^{128}$ Especially in these normative dimensions, the concepts of civilian and normative power (and similar) rest upon a conception of superiority. ${ }^{129}$ Underlying the normative stance, as the quotation of François Duchêne illustrates so well, is a renewed emphasis on civilization, that quintessential imperialist concept, which once again introduces symbolic oppositions and hierarchies, even if the latter was sometimes explicitly denied along with any colonial association. Yet a closer look this very negation illustrates the continuing mind-set, which I cannot illustrate better than with the following speech by JoséManuel Barroso a few years after his earlier statement on Europe as a 'non-imperial empire', but while still President of the European Commission, at the opening of the exhibition 'Europe meets the World' at the National Museum of Demark in Copenhagen in January 2012:

The exhibition also reminds us that Europe is not just about the markets [...], but Europe is about culture, Europe is about values, Europe is also about civilization - [a] civilization that has great moments, also darker moments to be honest, but Europe is about culture. [...] it comes from the ideas of the Enlightenment, one of the greatest moments of the European history and civilizations. We should not be afraid of the word 'civilization'.

This exhibition reminds us of how over centuries Europeans have helped shape the interconnected world in which we now live. In times of peace the European continent has been the forerunner in promoting ties of openness, trade, and exchange around the globe $[\ldots] .{ }^{130}$

The very negation of Europe's imperial and colonial past and its replacement by a shockingly ahistorical image of the continent as an open and benevolent civilization, popular not just with European commissioners but also with political thinkers such as Ian Manners, Ulrich Beck, Gerard Delanty and Jürgen Habermas, actually confirms its enduring impact. What, as British sociologist Gurminder K. Bhambra observed, makes the 'cosmopolitan' and 'reflexive' argument so repulsive is the contradiction between the claim for reflection and openness on the one hand, and the denial (or at least understatement) of Europe's colonial past and all it entails on the other. ${ }^{131}$

The reflective attitude that these authors refer to is not entirely fiction though: it refers to the self-critical, apologizing stance that Europe has taken towards its 'domestic' history - a self-criticism that non-European students sometimes find surprising and quite puzzling and which effectively underpinned the turn towards human rights - what Helle Porsdam has described as a form of 'Vergangenheitsbewältigung through law'. ${ }^{132}$ However, in an original and insightful assessment of European socalled 'speculative speeches' by leading European politicians, Bernhard Forchtner and Christoffer Kølvraa demonstrated how this 'self-critical narration of a "bitter 
past" is, paradoxically, transformed into a self-righteous attitude towards Europe's "others". 133 Ironically, the emphasis on development and human rights thus underpins a neo-imperialist 'civilizing mission' attitude: as Europe managed to overcome its 'bitter past', it views itself uniquely situated to 'teach' or lecture others, as comes to the fore in the following statement by Barroso's predecessor as President of the European Commission, Romano Prodi:

[...] Partly because of the strength it derives from our civilisation, Europe can and must be a credible partner and mediator in these new worlds, which have finally returned to history. Over the centuries, we have contended with many new realities that appeared from beyond our seas, and we have consistently forged new relationships with peoples and countries who differed from ourselves. The tradition that we have inherited has dominated history for this reason - this ability of ours to lead and to set an example to other peoples and races. (Emphasis added.) ${ }^{134}$

This of course it can only do by ignoring Europe's colonial past - hence human rights became, in the words of Hans Magnus Enzensberger, 'the last refuge of Eurocentrism'. ${ }^{135}$

It is difficult to escape the ethical dimension of this forgetting. Forgetting is not innocent. In the case of colonialism it is also about not recognizing the immense contribution of the colonies to the wealth and prosperity of Europe, an issue that I did not develop in this article but that should not be overlooked in a broader context. ${ }^{136}$ The issue is also related to that of guilt. Do present generations bear any responsibility for the crimes of their forefathers? The issue is often raised with regard to the European/German relationship with the Holocaust, which some like to see as 'Germany's' sole 'responsibility', but which, whether we like it or not, also applies somehow to Europeans with regard to the colonial past. In an interesting discussion, moral philosopher Kwame Anthony Appiah recently argued against recognizing guilt. ${ }^{137}$ However, there are two caveats. Appiah observed that when we share and feel connected, we may feel shame - or pride if the connection is with something positive. There thus is a connection, if not a moral responsibility. I would add another aspect: the moral duty not to repeat the errors of 'our' fathers. This 'moral duty' may be more compelling if we share, willingly or not, a common heritage and culture. Forgetting and denial, I would argue, increase the risk of repeating these errors remembering and recognizing, even without expressing guilt or even shame, in contrast may constitute an effective barrier. It makes a strong case, I believe, for not forgetting, for remembering, all the more so as the colonial heritage appears somehow to be returning in EU practices, like damp spots in the wallpaper.

Returning to the metaphor of the EU as empire, it is perhaps more fruitful to view the EU not as an empire, which it is emphatically not, but somehow, as historian Stella Ghervas argues, as a conglomerate of small states and former empires that transferred some sovereignty to supranational bodies. ${ }^{138}$ This far better explains the ambiguities and weaknesses of both 'domestic' and international EU politics, as these constitute a compromise of very different legacies, memories and ambitions. In this respect, European history continues exhibiting imperial features without being an empire itself. But it may still be the palimpsest of empire. 


\section{Acknowledgements}

This paper was discussed at the workshop From Empires to Empire? European Integration in Global Context, 1950s to $1990 \mathrm{~s}$ in the framework of the KollegForschergruppe (KFG) 'The Transformative Power of Europe', Berlin, 7-8 April 2016. I wish to thank the organizers Wolfram Kaiser and Kiran Klaus Patel as well as Tony Chafer, Robin de Bruin, Frank Gerits, Peo Hansen, Stefan Jonsson, Fabian Klose, Jacob Krumrey, Anne-Isabelle Richard and Pascaline Winand for helpful comments and suggestions. Some master students, in particular Melanie De Coninck and Koen Vandenweyer provided valuable information through their master theses. The Leibniz Institute for European History in Mainz, Germany, generously offered me a Senior Research Fellowship, which allowed me to complete this text.

\section{References and Notes}

1. T. Asad (2003) Formations of the Secular: Christianity, Islam, Modernity (Stanford: Stanford University Press), p 170.

2. Cf. P. Pasture (2015) Imagining European Unity since 1000 AD (Basingstoke: Palgrave Macmillan), pp. 80-81.

3. Peo Hansen and Stefan Jonsson wrote numerous path-breaking articles which finally culminate in their (long awaited) magnum opus P. Hansen and S. Jonsson (2014) Eurafrica: The Untold History of European Integration and Colonialism (London: Bloomsbury), For some important precursors see below, esp. notes 12-14. See also P. Pasture (2015) Imagining European Unity since 1000 AD (Basingstoke: Palgrave Macmillan); and K. Nicolaïdis, B. Sèbe and G. Maas (Eds), (2015) Echoes of Empire: Memory, Identity and Colonial Legacies (New York: I.B. Taurus).

4. For example N. Davies (1996) Europe: A History (Oxford: Oxford University Press), p. 1068. P. Lagrou (2009) Europe and the world: imperial legacies In: M. Telò (Ed.), The EU and Global Governance (London: Routledge), pp. 306-326. For a broader discussion of such arguments see P. Hansen and S. Jonsson (2014) Eurafrica: The Untold History of European Integration and Colonialism (London: Bloomsbury), pp. 262-265; and L. Kottos (2016) Europe between Imperial Decline and Quest for Integration: Pro-European Groups and the French, Belgian and British Empires (1947-1957) (Brussels: PIE Peter Lang).

5. A discussion on the relationship between European integration and empire, with a special emphasis on the role of public opinion, can be found in L. Kottos (2015) Linking Europe and Empire: making strategic choices on the eve of the Treaty of Rome. In: P. Winand, A. Benvenuti and M. Guderzo (Eds), The External Relations of the European Union (Brussels: PIE Peter Lang), pp. 311-328.

6. M. Shipway (2007) Decolonization and its Impact: A Comparative Approach to the End of the Colonial Empires (Malden: Blackwell), p. 51.

7. There is still no comprehensive history of the Commonwealth. F. Heinlein (2013) British Government Policy and Decolonisation, 1945-63: Scrutinising the Official Mind (London: Frank Cass), contains the best assessment of its origins.

8. F. Cooper (2014) Citizenship between Empire and Nation: Remaking France and French Africa 1945-1960 (Princeton: Princeton University Press)

9. A. Trunk (2007) Europa, ein Ausweg. Politische Eliten und europäische Identität in den 1950er Jahren (München: Oldenbourg), p. 157. 
10. R. de Bruin (2001) Dutch politics in the 1950s and the myth of inevitable Europeanization. In: J. Róka, (Ed.), Globalisation, Europeanization and Other Transnational Phenomena: Description, Analyses and Generalizations (Budapest: Budapest College of Communications and Business), pp. 382-390.

11. Extensively in P. Hansen and S. Jonsson (2014) Eurafrica: The Untold History of European Integration and Colonialism (London: Bloomsbury)

12. F. Heinlein (2002) British Government Policy and Decolonisation, 1945-1963. Scrutinising the Official Mind (London: Frank Cass), Y. Montarsolo (2010) L'Eurafrique, contrepoint de l'idée d'Europe - Le cas français de la fin de la deuxième guerre mondiale aux négociations des Traités de Rome (Aix-enProvence: Publications de l'Université de Provence), pp. 25-30.

13. On Belgian politics and attitudes towards Congo in the 1950s see especially. C. Young (1965) Politics in Congo: Decolonization and Independence (Princeton: Princeton University Press), G. Vanthemsche (2012) Belgium and the Congo, 1885-1980 (Cambridge: Cambridge University Press). On Belgian policies towards the Association see E. Deschamps (2009) L'Afrique belge et le projet de Communauté politique européenne (1952-1954). In: É. Remacle and P. Winand (Eds), America, Europe, Africa (1945-1973) (Brussels: PIE Peter Lang), pp. 307-323; V. Dujardin (2005) Le monde politique belge face au traité d'association des PTOM au Marché commun. In: M.-T. Bitsch and G. Bossuat (Eds), L'Europe unie et l'Afrique: De l'idée d'Eurafrique à la Convention de Lomé 1 (Brussels: Bruylandt), pp. 301-318; K. Vandenweyer (2012) Europese integratie en dekolonisatie: België, Congo en de associatie van de overzeese gebieden met de gemeenschappelijke markt (1955-1957) (Unpublished MA thesis History, KU Leuven).

14. The literature on Eurafrica has become quite substantial: M.-T. Bitsch and G. Bossuat (Eds), (2005) L'Europe unie et l'Afrique: De l'idée d'Eurafrique à la Convention de Lomé 1 (Brussels: Bruylandt), P. Hansen and S. Jonsson (2014) Eurafrica: The Untold History of European Integration and Colonialism (London: Bloomsbury); L. Kottos (2016) Europe between Imperial Decline and Quest for Integration: Pro-European Groups and the French, Belgian and British Empires (1947-1957) (Brussels: PIE Peter Lang); M. Liniger-Goumaz (1972) L'Eurafrique: Utopie ou Realité? (Yaounde: Editions CLE); Y. Montarsolo (2010) L'Eurafrique, contrepoint de l'idée d'Europe - Le cas français de la fin de la deuxième guerre mondiale aux négociations des Traités de Rome (Aix-en-Provence: Publications de l'Université de Provence); T. Moser (2000) Europäische Integration, Dekolonisation, Eurafrika: eine historische Analyse über Entstehungsbedingungen der Eurafrikanischen Gemeinschaft von der Weltwirtschaftskrise bis zum Jaunde-Vertrag, 1929-1963 (Baden-Baden: Nomos) constitute the key references. See also Ref. 42.

15. The Strasbourg plan: proposals for improving the economic relations between member states of the Council of Europe and the overseas countries with which they have constitutional links, Council of Europe, 1952. For a discussion see P. Hansen and S. Jonsson (2014) Eurafrica: The Untold History of European Integration and Colonialism (London: Bloomsbury), pp. 113-117; Y. Montarsolo (2010) L'Eurafrique, contrepoint de l'idée d'Europe - Le cas français de la fin de la deuxième guerre mondiale aux négociations des Traités de Rome (Aix-enProvence: Publications de l’Université de Provence), pp. 95-118; D. Avit (2005) La question de l'Eurafrique dans la construction de l'Europe de 1950 à 1957. Matériaux pour l'histoire de notre temps, 77, pp. 17-23; L. Kottos (2012) A 'European Commonwealth': Britain, the European League for Economic 
Co-operation, and European Debates on Empire, 1947-1957. Journal of Contemporary European Studies, 20(4), pp. 497-515.

16. Y. Montarsolo (2010) L'Eurafrique, contrepoint de l'idée d'Europe - Le cas français de la fin de la deuxième guerre mondiale aux négociations des Traités de Rome (Aix-en-Provence: Publications de l'Université de Provence), pp. 38-40 (and ff); G. Bossuat (1992) France, l'aide américaine et la construction européenne, 1944-1954 (Paris: Comité pour l'Histoire Économique et Financière de la France), vol. I, pp. 548-611.

17. P. Hansen and S. Jonsson (2014) Eurafrica: The Untold History of European Integration and Colonialism (London: Bloomsbury), pp. 119-128.

18. E. Tängerstad (2000) The Third World' as an element in the collective construction of a post-colonial European identity. In: B. Stråth (Ed.), Europe and the Other and Europe as the Other (Brussels: PIE Peter Lang 2000), pp. 157 193.

19. On American views on development see especially D. Ekbladh (2011) The Great American Mission: Modernization and the Construction of an American World Order (Princeton: Princeton University Press); C. Lancaster Foreign Aid: Diplomacy, Development, Domestic Policies (Chicago: University of Chicago Press); N. Cullather (2000) Development? It's history. Research Note, Diplomatic History, 24(4), pp. 641-653. Although especially French and Belgians were anxious about American opposition to European colonialism, the US hardly opposed the African colonial politics of its main European allies in the 1950s in practice. See A. Adamthwaite (2005) Britain, France, the United States and Euro-Africa, 1945-1949, and I.W. Wall (2005) Les États-Unis et la décolonisation de l'Afrique. Le mythe de l'Eurafrique. In: M.-T. Bitsch and G. Bossuat (Eds), L'Europe unie et l'Afrique: De l'idée d'Eurafrique à la Convention de Lomé 1 (Brussels: Bruylandt), pp. 119-132, 133-147; G. Garavini (2012) After Empires: European Integration, Decolonization and the Challenge from the Global South 1957-1986 (Oxford: Oxford University Press), pp. 17-19; N. Karagiannis (2004) Avoiding Responsibility: The Politics and Discourse of European Development Policy (London: Pluto Press), esp. pp. 23-45. That is not taking in account the Suez Crisis though, which showed the limits of American restraint towards European colonizers.

20. Draft of a Federal Pact, The Hague Conference 1948. Quoted in A. Hick (1991) The 'European Movement'. In: W. Lipgens and W. Loth (Eds), Documents on the History of European Integration, vol. IV, Transnational Organisations of Political Parties and Pressure Groups in the Struggle for European Union 19451950 (Berlin; New York: Walter de Gruyter), p. 316.

21. Council of Europe, 1952, quoted in P. Hansen and S. Jonsson (2014) Eurafrica: The Untold History of European Integration and Colonialism (London: Bloomsbury). 103-104.

22. F. Cooper (1996) Decolonization and African Society: The Labor Question in French and British Africa (Cambridge: Cambridge University Press); M. Rempe (2011) Decolonization by Europeanization? The early EEC and the transformation of French-African relations. Freie Universität Berlin, KFG Working Paper Series 27 (http://userpage.fu-berlin.de/kfgeu/kfgwp/wpseries/WorkingPaperKFG_27.pdf).

23. Quoted from a cabinet meeting 21 February 1957 by U. Vahsen (2010) Eurafrikanische Entwicklungskooperation. Die Assozierungspolitik der EWG gegenüber dem subsaharischen Afrika in den 1960er Jahren (Stuttgart: Steiner), p. 99. 
24. D. Van Laak (2010) Detours around Africa: the connection between developing colonies and integrating Europe. In: A. Badenoch and A. Fickers (Eds), Materializing Europe. Transnational Infrastructures and the Project of Europe (Basingstoke: Palgrave Macmillan), pp. 27-43.

25. On this passage see P. Hansen and S. Jonsson (2014) Eurafrica: The Untold History of European Integration and Colonialism (London: Bloomsbury), pp. 123-124; Y. Montarsolo (2010) L'Eurafrique, contrepoint de l'idée d'Europe Le cas français de la fin de la deuxième guerre mondiale aux négociations des Traités de Rome (Aix-en-Provence: Publications de l'Université de Provence), pp. 85-91.

26. R. Girault (1989) La France entre l'Europe et l'Afrique. In: E. Serra (Ed.), La relance européenne et les traités de Rome (Brussels: Bruylant), pp. 351-378; See also extensively G. Migani (2008) La France et l'Afrique sub-saharienne, 19571963. Histoire d'une decolonization entre idéaux eurafricains et politique de puissance (Brussels: PIE Peter Lang).

27. F. Leikam (2011) Empire, Entwicklung und Europa: Die Europapolitik Großbritanniens und die Entwicklungsländer im Commonwealth, 1945-75 (Augsburg: Wißner), F. Heinlein (2002) British Government Policy and Decolonisation, 1945-1963: Scrutinising the Official Mind (London: Frank Cass), pp. 137-143; F. Leikam (2015) A matter of preference: Commonwealth Africa, Britain and the EEC Association System, 1957-75. In: P. Winand, A. Benvenuti and M. Guderzo (Eds), The External Relations of the European Union (Brussels: PIE Peter Lang), pp. 293-310.

28. See P. Hansen and S. Jonsson (2014) Eurafrica: The Untold History of European Integration and Colonialism (London: Bloomsbury), L. Kottos (2012) A 'European Commonwealth': Britain, the European League for Economic Co-operation, and European Debates on Empire, 1947-1957. Journal of Contemporary European Studies, 20(4), pp. 497-515; L. Kottos (2015) Linking Europe and Empire: making strategic choices on the eve of the Treaty of Rome. In: P. Winand, A. Benvenuti and M. Guderzo (Eds), The External Relations of the European Union (Brussels: PIE Peter Lang), pp. 311-328; L. Kottos (2016) Europe between Imperial Decline and Quest for Integration: Pro-European Groups and the French, Belgian and British Empires (1947-1957) (Brussels: PIE Peter Lang); F. Leikam (2011) Empire, Entwicklung und Europa: Die Europapolitik Großbritanniens und die Entwicklungsländer im Commonwealth, 1945-75 (Augsburg: Wißner); F. Leikam (2015) A matter of preference: Commonwealth Africa, Britain and the EEC Association System, 1957-75. In: P. Winand, A. Benvenuti and M. Guderzo (Eds), The External Relations of the European Union (Brussels: PIE Peter Lang), pp. 293-310; A. May (Ed.), (2001) Britain, The Commonwealth and Europe: The Commonwealth and Britain's Applications to Join the European Communities (Basingstoke: Palgrave Macmillan); F. Heinlein (2013) British Government Policy and Decolonisation, 1945-63: Scrutinising the Official Mind (London: Frank Cass).

29. F. Cooper (2014) Citizenship between Empire and Nation: Remaking France and French Africa 1945-1960 (Princeton: Princeton University Press), p. 268. A detailed assessment of the negotiations can be found in P. Hansen and S. Jonsson (2014) Eurafrica: The Untold History of European Integration and Colonialism (London: Bloomsbury), 147-238; G. Migani (2008) La France et l'Afrique sub-saharienne, 1957-1963. Histoire d'une decolonization entre idéaux eurafricains et politique de puissance (Brussels: PIE Peter Lang). See also L. Sicking (2004) A colonial echo: France and the colonial dimension of the European Community. French Colonial History, 5, pp. 207-228. 
30. Especially A. Zischka (1951) Afrika. Europas Gemeinschaftsaufgabe Nr. 1 (Gerhard Stalling: Oldenburg), (French translation 1952). Notwithstanding his Nazi past, Zischka's ideas on Eurafrica were quite influential and representative for the time. See Y. Montarsolo (2010) L'Eurafrique, contrepoint de l'idée d'Europe - Le cas français de la fin de la deuxième guerre mondiale aux négociations des Traités de Rome (Aix-en-Provence: Publications de l'Université de Provence), pp. 98-102; U. Vahsen (2010) Eurafrikanische Entwicklungskooperation. Die Assozierungspolitik der EWG gegenüber dem subsaharischen Afrika in den 1960er Jahren (Stuttgart: Steiner), pp. 122-138 (and ff); D. Van Laak (2004) Imperiale Infrastruktur. Deutsche Planungen für eine Erschließung Afrikas 1880 bis 1960 (Paderborn: F. Schöningh), pp. 335-353; and D. Van Laak (2010) Detours around Africa: the connection between developing colonies and integrating Europe. In: A. Badenoch and A. Fickers (Eds), Materializing Europe. Transnational Infrastructures and the Project of Europe (Basingstoke: Palgrave Macmillan), pp. 27-43.

31. G. Mollet (1958) Bilan et perspectives socialistes (Paris: Plon), pp. 35, 45-46, 56 See the discussion in T.C. Imlay (2013) International socialism and decolonization during the 1950s: competing rights and the postcolonial order. The American Historical Review, 118, pp 1105-1132, p. 1120. See also the penetrating critique of Y. Montarsolo (2010) L'Eurafrique, contrepoint de l'idée d'Europe - Le cas français de la fin de la deuxième guerre mondiale aux négociations des Traités de Rome (Aix-en-Provence: Publications de l'Université de Provence), pp. 65-69 on this 'colonial federalism'; A.-I. Richard (2014) The limits of solidarity. Europeanism, anti-colonialism and socialism at the Congress of the Peoples of Europe, Asia and Africa at Puteaux, 1948. European Review of History, 21(4), pp. 519-537; and P. Van Kemseke (2006) Towards an Era of Development: The Globalization of Socialism and Christian Democracy 1945-1965 (Leuven: Leuven University Press).

32. A similar thought in the memoires of Baron Robert Rothschild, head of the cabinet of PM P.H. Spaak and as such one of the architects of the Rome treaties: R. Rothschild (1997) Un phénix nommé Europe: mémoires 1945-1995 (Brussels, Racine), p. 180.

33. On these dilemmas see particularly F. Cooper (2014) Africa in the World: Capitalism, Empire, Nation-State (Cambridge, MA: Harvard University Press), F. Cooper (2014) Citizenship between Empire and Nation: Remaking France and French Africa 1945-1960 (Princeton: Princeton University Press); A.-I. Richard (2014) The limits of solidarity. Europeanism, anti-colonialism and socialism at the Congress of the Peoples of Europe, Asia and Africa at Puteaux, 1948. European Review of History, 21(4), p. 529.

34. http://eur-lex.europa.eu/legal-content/EN-FR/TXT/?uri=URISERV:xy0023\&fro$\mathrm{m}=\mathrm{EN}$. It gave way to the historiographical myth that Eurafrica could be interpreted as a step in the process of decolonization. See Note 3.

35. For example, Le Chancelier Adenauer: l'association des territoires d'outre-mer n'a rien de commun avec le colonialisme, Le Monde, 24 February 1957, p. 3. P. Hansen and S. Jonsson (2014) Eurafrica: The Untold History of European Integration and Colonialism (London: Bloomsbury), pp. 247-252 discuss this and other reactions.

36. F. Cooper (2010) Writing the history of development. In: C.R. Unger, S. Malinowski and A. Eckert (Eds), Modernizing Missions: Approaches to 'Developing' the Non-Western World after 1945. Special issue of Journal of Modern European History, 8(1), pp. 5-23, p. 12. 
37. Brussels, Historical Archives of the Council of the EU, Négociations des traités instituant le CEE et la CEEA (1955-1957), CM3. Conférence des ministres des Affaires étrangères et signature des traités de la CEE et de la CEEA, Rome, 25 March 1957, CM3/ NEGO/098, online http://www.cvce.eu/obj/rede_van_joseph_luns_rome_25_maart_1957-nl-897c0a02-4e66-445f-82ad-5939f78008f0. html. The French version of the original Dutch text translates as zijn grootste taak in de wereldbeschaving as sa grande mission civilisatrice mondiale. It should be noted though that the Netherlands had fiercely opposed the association, partly because of its colonial dimension, partly because it did not agree with a preferential treatment of former Belgian and French colonies. See A.G. Harryvan and J. van der Horst (2005) A Bumpy road to Lomé. The Netherlands, Association and the Yaounde Treaties 1956-1969. In: M.-T. Bitsch and G. Bossuat (Eds), L'Europe unie et l'Afrique: De l'idée d'Eurafrique à la Convention de Lomé 1 (Brussels: Bruylandt), pp. 319-343.

38. V. Dimier (2014) The Invention of a European Development Aid Bureaucracy: Recycling Empire (Basingstoke: Palgrave Macmillan), pp. 13-15. The issue of the representation was a major factor in the demise of the EPC. See E. Deschamps (1999) Un rendez-vous historique manqué? La 'Petite Europe', l'Afrique et le projet de Communauté Politique Européenne (1952-1954). European Review of History, 6(2), pp. 251-263.

39. Wolfgang Schmale has observed that civilizing missions and imperialism/ colonialism were sometimes dissociated: the power of ideas could do without the power of guns. W. Schmale (2011) Before self-reflexivity: imperialism and colonialism in the early discourse of European integration. In: M. Spiering and M. Wintle (Eds), European Identity and the Second World War (Basingstoke: Palgrave Macmillan), pp. 186-201, p. 192.

40. V. Dimier (2014) The Invention of a European Development Aid Bureaucracy: Recycling Empire (Basingstoke: Palgrave Macmillan), pp. 14-15; M. Lister (1988) The European Union and Developing World (Aldershot: Avebury), p. 14. A fruitful discussion of the term neo-colonialism is in G. Martin (2002) Africa in World Politics: A Pan-African Perspective (Trenton NJ/ Asmara, Eritrea: Africa World Press), pp. 1-22.

41. Compare with F. Fanon (1963) The Wretched of the Earth (New York: Weidenfeld), p. 218. 'The intellectual who is Arab and French or Nigerian and English, when he comes up against the need to take on two nationalities, chooses, if he wants to remain true to himself, the negation of one of these determinations'.

42. Although most works on Eurafrica include the major statements of the main African leaders, the African attitudes towards Eurafrica have hardly been analysed. For first attempts see F. Cooper (2014) Citizenship between Empire and Nation: Remaking France and French Africa 1945-1960 (Princeton: Princeton University Press), pp. 214-278, who puts the discussion in a broader and changing African context. See also D. Avit (2005) La question de l'Eurafrique dans la construction de l'Europe de 1950 à 1957. Matériaux pour l'histoire de notre temps, 77, pp. 17-23; P. Dramé and S. Saul (2004) Le projet d'Eurafrique en France (1946-1960): quête de puissance ou atavisme colonial? Guerres mondiales et conflits contemporains, 4, pp. 95-114; J. Fremigacci (2005) Les parlementaires africains face à la construction européenne, 1953-1957. Matériaux pour l'histoire de notre temps, 77, pp. 5-16; S. Huber (2009) Dialogue avec le Tiers Monde: l'Europe communautaire à la recherche d'une identité postcoloniale, Relations internationales, 140(4), pp. 19-36 and the pioneering 
work of Anne-Isabelle Richard (2016) The Consultative Assembly of the Council of Europe as a platform for African Interests. Paper presented at the KFG workshop From Empires to Empire? Berlin, 7-8 April 2016. Y. Montarsolo (2010) L'Eurafrique, contrepoint de l'idée d'Europe - Le cas français de la fin de la deuxième guerre mondiale aux négociations des Traités de Rome (Aix-en-Provence: Publications de l'Université de Provence) focuses especially on Senghor.

43. Cf. W. Kaiser, S. Krankenhagen and K. Poehls (2014) Exhibiting Europe in Museums. Transnational Networks, Collections, Narratives, and Representations (Oxford: Berghahn)

44. M. Shipway (2007) Decolonization and its Impact: A Comparative Approach to the End of the Colonial Empires (Malden: Blackwell), p. 51.

45. K.K. Patel (2013) Provincialising European Union: co-operation and integration in Europe in a historical perspective. Contemporary European History, 22, pp. 649-673.

46. G. Feindt, F. Krawatzek, D. Mehler, F. Pestel and R. Trimçev (2014) Entangled memory. toward a third wave in memory studies. History and Theory, 53, pp. 24 44. The issue of the forgetting of European colonial and imperial pasts is discussed in E. Buettner (2016) Europe after Empire: Decolonization, Society and Culture (Cambridge: Cambridge University Press), pp. 417-490 (Eurafrica briefly p. 500).

47. Cf. P. Pichler (2018) European Union cultural history: introducing the theory of 'paradoxical coherence' to start mapping a field of research. Journal for European Integration History, 40(1): (https://doi.org/10.1080/07036337.2017.1404050).

48. C. Leggewie with A. Lang (2011) Der Kampf um die europäische Erinnerung. Ein Schlachtfeld wird besichtigt (München: C.H. Beck), See also J. Jansen (2010) Politics of remembrance, colonialism and the Algerian War of Independence in France. In: M. Pakier and B. Stråth (Eds), A European Memory? Contested Histories and Politics of Remembrance (New York; Oxford: Berghahn), pp. 275-293. Compare, inter alia, A. Assmann (2012) Auf dem Weg zu einer europäischen Gedächtniskultur? (Vienna: Picus); C. Bottici and B. Challand (2013) Imagining Europe: Myth, Memory, and Identity (Cambridge: Cambridge University Press); C. Joerges and P. Blokker with C. Engert (Eds), (2005) Confronting Memories. Special issue German Law Journal, 6(2), pp. 244-561; J.T. Checkel and P.J. Katzenstein (Eds), (2009) European Identity (Cambridge: Cambridge University Press); R.K. Herrmann, T. Risse and M.B. Brewer (Eds), (2004) Transnational Identities: Becoming European in the EU (Lanham: Rowman \& Littlefield); S. Macdonald (2013) Memorylands: Heritage and Identity in Europe Today (London: Routledge); M. Sassatelli (2009) Becoming Europeans: Cultural Identity and Cultural Policies (Basingstoke: Palgrave Macmillan); C. Shore (2000) Building Europe: The Cultural Politics of European Integration (London: Routledge). Also B. Sèbe (2015) Towards cosmopolitan perspectives on empires and their echoes? The case for a European framework. In: K. Nicolaïdis, B. Sèbe and G. Maas (Eds), (2015) Echoes of Empire: Memory, Identity and Colonial Legacies (New York: I.B. Taurus), pp. 123-140 stops short of including the EC/EU.

49. See especially M. Sassatelli (2009) Becoming Europeans: Cultural Identity and Cultural Policies (Basingstoke: Palgrave Macmillan), pp. 39-41; G. Quenzel (2005) Konstruktionen von Europa: Die europäische Identität und die Kulturpolitik der Europäischen Union (Bielefeld: transcript Verlag). On the cultural policies of the CoE see J. Kruse (1993) Europäische Kulturpolitik am Beispiel des 
Europarats (Berlin: Lit); B. Wassenberg (2012) Histoire du Conseil de l'Europe (1949-2009) (Brussels: PIE Peter Lang).

50. O. Wæver (1998) Insecurity, security and asecurity in the West European nonwar community. In: E. Adler and M. Barnett (Eds), Security Communities (Cambridge: Cambridge University Press), pp. 69-118, p. 90.

51. C. Bottici (2010) European identity and the politics of remembrance. In: K. Tilmans, F. van Vree and J. Winter (Eds), Performing the Past. Memory, History and Identity in Modern Europe (Amsterdam: Amsterdam University Press), pp. 335-361. A. Trunk (2007) Europa, ein Ausweg. Politische Eliten und europäische Identität in den 1950er Jahren (München: Oldenbourg, 2007), p. 164 quotes the then Belgian Minister of Foreign Affairs P.-H. Spaak (later President of the CoE and of NATO) referring to the 'three dates' that seemed to determine the 'history of Europe and the world' (!) 1870, 1914 and 1939. See also T. Judt (1992) The past is another country: myth and memory in postwar Europe. Daedalus, 121(4), 83-118. In his magnum opus, T. Judt (2005) Postwar: A History of Europe Since 1945 (New York: Penguin), Judt did pay some attention to the impact of colonization and decolonization. Others still do not, e.g. D. Stone (2014) Goodbye to All That? The Story of Europe Since 1945 (Oxford: Oxford University Press).

52. See also G. Garavini (2007) The colonies strike back: the impact of the third world on Western Europe, 1968-1975. Contemporary European History, 16(3), pp. 299-319.

53. O. Calligaro (2015) Legitimation through remembrance? The changing regimes of historicity of European integration. Journal of Contemporary European Studies, 23(3), pp. 330-343. F. Larat (2005) Presenting the past: political narratives on European history and the justification of EU integration. German Law Journal, 6(2), pp. 273-290. On 'presentism' as a historical time mode see F. Hartog (2015) Regimes of Historicity: Presentism and the Experience of Time (New York: Columbia University Press); A. Assmann (2013) Transformations of the modern time regime. In: C. Lorenz and B. Bevernage (Eds), Breaking up Time: Negotiating the Borders between Present, Past and Future (Göttingen: Vandenhoeck \& Ruprecht), pp. 39-56.

54. On the importance of trauma see J. Winter (2010) Introduction: the performance of the past: memory, history, identity. In: K. Tilmans, F. van Vree and J. Winter (Eds), Performing the Past. Memory, History and Identity in Modern Europe (Amsterdam: Amsterdam University Press), pp. 11-23; C. Bottici and B. Challand (2013) Imagining Europe: Myth, Memory, and Identity (Cambridge: Cambridge University Press), pp. 51ff. Note that colonial memories are not mentioned in these works.

55. This idea is further developed in G. Quenzel (2005) Konstruktionen von Europa: Die europäische Identität und die Kulturpolitik der Europäischen Union (Bielefeld: transcript Verlag), On the importance of forgetting see A. Assmann (2012) Auf dem Weg zu einer europäischen Gedächtniskultur? (Vienna: Picus); A. Assmann and U. Frevert (1999) Geschichtsvergessenheit - Geschichtsvergessenheit. Vom Umgang mit deutschen Vergangenheiten nach 1945 (Stuttgart: DVA); C. Meier (2010) Das Gebot zu vergessen und die Unabweisbarkeit des Erinnerns: Vom öffentlichen Umgang mit schlimmer Vergangenheit (München: Siedler).

56. Cf. E. Buettner (2016) Europe after Empire: Decolonization, Society and Culture (Cambridge: Cambridge University Press), pp. 474-490; B. Porter (2015) Epilogue: after-images of empire. In: K. Nicolaïdis, B. Sèbe and G. Maas (Eds), 
Echoes of Empire: Memory, Identity and Colonial Legacies (New York: I.B. Taurus), pp. 393-406.

57. J. Jansen (2010) Politics of remembrance, colonialism and the Algerian War of Independence in France. In: M. Pakier and B. Stråth (Eds), A European Memory? Contested Histories and Politics of Remembrance (New York; Oxford: Berghahn), pp. 275-293.

58. C. Leggewie with A. Lang (2011) Der Kampf um die europäische Erinnerung. Ein Schlachtfeld wird besichtigt (München: C.H. Beck), On British memories with relation to Europe see A. Deighton (2002) The past in the present: British imperial memories and the European question. In: J.-W. Mueller (Ed.), Memory and Power in Postwar Europe (Cambridge: Cambridge University Press), pp. 100-120.

59. The reference to the Eurafrican ambition of the Schuman Declaration quoted earlier (Ref. 29) was omitted from public versions of the declaration by the EU (recently rectified though), as well as by the Institut Robert Schuman pour l'Europe, the European Movement and even Leiden University's Schuman Plan Collection. See E. Deschamps (2011) Robert Schuman, un apôtre oublié de l'Eurafrique? In: S. Schirman (Ed.), Quelles architectures pour quelle Europe: Des projets d'une Europe unie à l'Union européenne (1945-1992) (Brussels: PIE Peter Lang), p. 75; P. Hansen and S. Jonsson (2014) Eurafrica: The Untold History of European Integration and Colonialism (London: Bloomsbury), note 141.

60. L. Hölscher (1989) Geschichte und Vergessen. Historische Zeitschrift, 249(1), pp. 1-17; F. Whitling (2010) Damnatio Memoriae and the power of remembrance. Reflections on memory and history. In: M. Pakier and B. Stråth (Eds), A European Memory? Contested Histories and Politics of Remembrance (New York; Oxford: Berghahn), pp. 87-97.

61. Cf. T. Bentley (2015) Empires of Remorse: Narrative, Postcolonialism and Apologies for Colonial Atrocity (London: Routledge), See also J. Jansen (2010) Politics of remembrance, colonialism and the Algerian War of Independence in France. In: M. Pakier and B. Stråth (Eds), A European Memory? Contested Histories and Politics of Remembrance (New York; Oxford: Berghahn) and, for a general assessment, B. Bevernage (2012) History, Memory, and StateSponsored Violence: Time and Justice (New York: Routledge).

62. T. Shepard (2008) The Invention of Decolonization: The Algerian War and the Remaking of France (Ithaca: Cornell University Press), p. 6. See K. Nicolaïdes (2015) Southern barbarians? A post-colonial critique of EUniversalism. In: K. Nicolaïdis, B. Sèbe and G. Maas (Eds), Echoes of Empire: Memory, Identity and Colonial Legacies (New York: I.B. Taurus), pp. 283-303.

63. J. Jansen (2010) Politics of remembrance, colonialism and the Algerian War of Independence in France. In: M. Pakier and B. Stråth (Eds), A European Memory? Contested Histories and Politics of Remembrance (New York; Oxford: Berghahn), pp. 275-293.

64. Which is even the case for G. Garavini (2012) After Empires: European Integration, Decolonization and the Challenge from the Global South 1957-1986 (Oxford: Oxford University Press), pp. 46-48.

65. Frank Gerits (2016) made a similar argument at the workshop From Empires to Empire? in his contribution: The EEC as a Pan-White Project: European Integration through South African and Ghanaian Eyes (1950-1966). Paper presented at the KFG workshop, From Empires to Empire? Berlin, 7-8 April 2016.

66. See especially U. Vahsen (2010) Eurafrikanische Entwicklungskooperation. Die Assozierungspolitik der EWG gegenüber dem subsaharischen Afrika in den 
1960er Jahren (Stuttgart: Steiner), G. Garavini (2012) After Empires: European Integration, Decolonization and the Challenge from the Global South 1957-1986 (Oxford: Oxford University Press).

67. On the evolving British and Commonwealth attitudes see F. Leikam (2015) A matter of preference: Commonwealth Africa, Britain and the EEC Association System, 1957-75. In: P. Winand, A. Benvenuti and M. Guderzo (Eds), The External Relations of the European Union (Brussels: PIE Peter Lang), pp. 293-310. A more critical assessment in F. Gerits (2016) From Empires to Empire? Contribution to: The EEC as a Pan-White Project: European Integration through South African and Ghanaian Eyes (1950-1966). Paper presented at the KFG workshop, From Empires to Empire? Berlin, 7-8 April 2016.

68. V. Dimier (2014) The Invention of a European Development Aid Bureaucracy: Recycling Empire (Basingstoke: Palgrave Macmillan), pp. 22-42.

69. P. Hansen and S. Jonsson (2014) Eurafrica: The Untold History of European Integration and Colonialism (London: Bloomsbury), pp. 252-259.

70. Some political scientists do compare the EU to an empire though, in terms of its relationship with its 'nations', contrasted with the nation-state. For example, U. Beck and E. Grande (2007) Cosmopolitan Europe (Cambridge: Polity), J. Zielonka (2006) Europe as Empire (Oxford: Oxford University Press). I find the historical representation of empire in these works problematic though. S. Malešvić (2017) The foundations of statehood: empires and nation-states in the longue durée. Thesis Eleven, 139(1), pp. 1-17 offers a recent state of the art of the discussion about empire and nation-states. See also P. Pasture (2015) Imagining European Unity since 1000 AD (Basingstoke: Palgrave Macmillan), pp. 80-81.

71. H. Schulz-Forberg and B. Stråth (2010) The Political History of European Integration. The Hypocrisy of Democracy-through-Market (London: Routledge), On the legitimacy problem see C. Bottici and B. Challand (2013) Imagining Europe: Myth, Memory, and Identity (Cambridge: Cambridge University Press), pp. 15-39.

72. https://www.nobelprize.org/nobel_prizes/peace/laureates/2012/press.html.

73. P. Pasture (2015) Imagining European Unity since 1000 AD (Basingstoke: Palgrave Macmillan), gives several examples from different times.

74. D. Allen (1996) Conclusions: the European rescue of national foreign policy. In: C. Hill (Ed.), The Actors in European Foreign Policy (London: Routledge), pp. 288-304. On the 'modernization' of European foreign policy see S. Keuckeleire and T. Delreux (2014) The Foreign Policy of the European Union (Basingstoke: Palgrave Macmillan), pp. 116-134.

75. S. Moyn (2012) The Last Utopia: Human Rights in History (Cambridge, MA: Harvard University Press), p. 1.

76. For recent overviews of the discussion see K. Cmiel (2011) The recent history of human rights. In: A. Iriye, P. and W.I. Hitchcock (Eds), The Human Rights Revolution: An International History (Oxford: Oxford University Press), pp. 2751; S.-L. Hoffmann (2011) Genealogies of human rights. In: S.-L. Hoffmann (Ed.), Human Rights in the Twentieth Century (Cambridge: Cambridge University Press), pp. 1-28; S.-L. Hoffmann (2016) Human rights and history. Past and Present, 232, pp. 279-310; D.O. Pendas (2012) Toward a new politics? On the recent historiography of human rights. Contemporary European History, 21(1), pp. 95-111; P. Slotte and M. Halme-Tuomisaari (Eds), (2015) Revisiting the Origins of Human Rights (Cambridge: Cambridge University Press). I develop my argument more extensively in P. Pasture (2018) The invention of European human rights. History: The Journal of the Historical Association (in press). 
77. Summaries of the discussion in J. Eckel (2014) Human rights and decolonization: new perspectives and open questions. Humanity Journal, 10 June 2014 (http://humanityjournal.org/issue-1/human-rights-and-decolonization-newperspectives-and-open-questions/); S.L.B. Jensen (2016) The Making of International Human Rights: The 1960s, Decolonization, and the Reconstruction of Global Values (Cambridge: Cambridge University Press); F. Klose (2016) Human rights for and against Empire - legal and public discourses in the age of decolonisation. Journal of the History of International Law, 18, pp. 317-338.

78. See A.W.B. Simpson (2004) Human Rights and the End of Empire: Britain and the Genesis of the European Convention (Oxford: Oxford University Press)

79. For example M.R. Madsen (2014) International human rights and the transformation of European society: from 'Free Europe' to the Europe of human rights. In: M.R. Madsen and C. Thornhill (Eds), Law and the Formation of Modern Europe: Perspectives from the Historical Sociology of Law (Cambridge: Cambridge University Press), pp. 245-274, p. 140; H. Porsdam (2011) Human rights and European identity since World War II: Vergangenheitsbewältigung through Law. In: M. Spiering and M. Wintle (Eds), European Identity and the Second World War (Basingstoke: Palgrave Macmillan), pp. $21-$ 36.

80. G. de Búrca (2011) The road not taken: the EU as a global human rights actor. American Journal of International Law, 105, pp. 649-693.

81. H. Joas (2013) The Sacredness of the Person: A New Genealogy of Human Rights (Washington, DC: Georgetown University Press), S. Moyn (2015) Christian Human Rights (Philadelphia: University of Pennsylvania Press); S. Moyn (2012) The Last Utopia: Human Rights in History (Cambridge, MA: Harvard University Press).

82. M. Duranti (2017) The Conservative Human Rights Revolution: European Identity, Transnational Politics, and the Origins of the European Convention (Oxford: Oxford University Press)

83. E.D. Weitz (2008) From the Vienna to the Paris system: international politics and the entangled histories of human rights, forced deportations, and civilizing missions. The American Historical Review, 113(5), pp. 1313-1343 and E.D. Weitz (2015) Self-determination: how a German enlightenment idea became the slogan of national liberation and a human right. The American Historical Review, 120(2), pp. 462-496. See also J. Fisch (2015) The Right of SelfDetermination of Peoples: The Domestication of an Illusion (Cambridge: Cambridge University Press). The Convention also lacked social rights as formulated in the Universal Declaration of Human Rights (UDHR) proclaimed by the United Nations on 10 December 1948.

84. It should be noted that the sovereignty argument was not only invoked by colonial empires: also non-colonial states did not sign, such as Italy (1973) and Switzerland (1974).

85. F. Klose (2011) 'Source of embarrassment' - human rights, state of emergency, and the wars of decolonization. In: S.-L. Hoffmann (Ed.), Human Rights in the Twentieth Century (Cambridge: Cambridge University Press), pp. 237-257; F. Klose (2014) Europe as a colonial project: a critique of its anti-liberalism. In: D. Gosewinckel (Ed.), Anti-liberal Europe: A Neglected Story of Europeanization (Oxford: Berghahn), pp. 50-71.

86. A.-I. Richard (2016) The Consultative Assembly of the Council of Europe as a platform for African Interests. Paper presented at the KFG workshop From Empires to Empire? Berlin, 7-8 April 2016. 
87. For example G. de Búrca (2011) The road not taken: the EU as a global human rights actor. American Journal of International Law, 105, pp. 649-693.

88. Obviously the policy of the ECJ provoked a lot of reaction. See as main references G. de Búrca (2011) The road not taken: the EU as a global human rights actor. American Journal of International Law, 105, pp. 668. ff.; M.R. Madsen (2013) Human rights and European integration: from institutional divide to convergent practice. In: N. Kauppi (Ed.), A Political Sociology of Transnational Europe (Colchester: ECPR), pp. 147-165; J.H.H. Weiler (1986) Eurocracy and distrust. Some questions concerning the role of the European Court of Justice in the protection of fundamental rights in the legal order of the communities. Washington Law Review, 61, pp. 1103-1142.

89. M.R. Madsen (2016) The challenging authority of the European Court of Human Rights: from Cold War legal diplomacy to the Brighton Declaration and backlash. Law and Contemporary Problems, 79(1), pp. 141-178. pp. 152, 143.

90. L. Ferrari (2015) The European Community as a promoter of human rights in Africa and Latin America, 1970-80. Journal of European Integration History, 21 (2), pp. 217-230, p. 222; L. Ferrari (2016) Sometimes Speaking with a Single Voice: The European Community as an International Actor, 1969-1979 (Brussels: PIE Peter Lang).

91. T. Buchanan (2010) Human rights, the memory of war and the making of a 'European' identity, 1945-1975. In: M. Conway and K.K. Patel (Eds), Europeanization in the Twentieth Century: Historical Approaches (Basingstoke: Palgrave Macmillan), pp. 157-171; R. Davy (2009) Helsinki myths: setting the record straight on the Final Act of the CSCE, 1975. Cold War History, 9(1), pp. 1-22; S.-L. Hoffmann (2011) Genealogies of human rights. In: S.-L. Hoffmann (Ed.), Human Rights in the Twentieth Century (Cambridge: Cambridge University Press), pp. 1-28; S.-L. Hoffmann (2016) Human rights and history. Past and Present, 232, pp. 279-310; M. Mazower (2012) Governing the World: The History of an Idea (New York, Allen Lane), p. 320 ff; D. Möckli (2009) European Foreign Policy during the Cold War. Heath, Brandt, Pompidou and the Dream of Political Unity (New York: I.B. Tauris), ch. 3; S. Moyn (2012) The Last Utopia: Human Rights in History (Cambridge, MA: Harvard University Press), pp. 172 (and ff.); N. Piers Ludlow (2007) European integration and the Cold War: Ostpolitik-Westpolitik, 1965-1973 (London: Routledge); A. Romano (2014) Untying Cold War knots: the EEC and Eastern Europe in the long 1970s. Cold War History, 14(2), pp. 153-173; A. Romano (2009) From Détente in Europe to European Détente. How the West Shaped the Helsinki CSCE (Brussels: PIE Peter Lang); S.B. Syder (2011) Principles overwhelming tanks: human rights and the end of the Cold War. In: A. Iriye, P. and W.I. Hitchcock (Eds), The Human Rights Revolution: An International History (Oxford: Oxford University Press), pp. 265-283.

92. M. Holland and M. Doidge (2012) Development Policy of the European Union (Basingstoke: Palgrave Macmillan), p. 50.

93. G. Garavini (2012) After Empires: European Integration, Decolonization and the Challenge from the Global South 1957-1986 (Oxford: Oxford University Press), p. 46. See also F. Cooper (2010) Writing the history of development. In: C.R. Unger, S. Malinowski and A. Eckert (Eds), Modernizing Missions: Approaches to 'Developing' the Non-Western World after 1945. Special issue of Journal of Modern European History, 8(1), pp. 5-23, p. 12.

94. Intervention in the European Parliamentary Assembly, 16 September 1963, quoted in S. Huber (2009) Dialogue avec le Tiers Monde: l'Europe 
communautaire à la recherche d'une identité postcoloniale. Relations internationales, 140(4), pp. 19-36, p. 25.

95. F. Gerits (2016) From Empires to Empire? Contribution to: The EEC as a PanWhite Project: European Integration through South African and Ghanaian Eyes (1950-1966). Paper presented at the KFG workshop, From Empires to Empire? Berlin, 7-8 April 2016.

96. F. Leikam (2015) A matter of preference: Commonwealth Africa, Britain and the EEC Association System, 1957-75. In: P. Winand, A. Benvenuti and M. Guderzo (Eds), The External Relations of the European Union (Brussels: PIE Peter Lang), p. 301.

97. See especially E. Jones and C. Weinhardt (2015) Echoes of colonialism in trade negotiations between the European Union and African, Caribbean and Pacific Countries. In: K. Nicolaïdes, B. Sèbe and G. Maas (Eds), Echoes of Empire: Memory, Identity and Colonial Legacies (New York: I.B. Taurus), pp. 226-250; U. Vahsen (2010) Eurafrikanische Entwicklungskooperation. Die Assozierungspolitik der EWG gegenüber dem subsaharischen Afrika in den 1960er Jahren (Stuttgart: Steiner), pp. 184-198; F. Leikam (2015) A matter of preference: Commonwealth Africa, Britain and the EEC Association System, 1957-75. In: P. Winand, A. Benvenuti and M. Guderzo (Eds), The External Relations of the European Union (Brussels: PIE Peter Lang), pp. 293-310.

98. V. Dimier (2014) The Invention of a European Development Aid Bureaucracy: Recycling Empire (Basingstoke: Palgrave Macmillan), pp. 22-42, on the tensions pp. 59-79. See also G. Migani (2008) La France et l'Afrique subsaharienne, 1957-1963. Histoire d'une decolonization entre idéaux eurafricains et politique de puissance (Brussels: PIE Peter Lang), pp. 193-207 (and ff. until p. 247) and M. Rempe (2011) Decolonization by Europeanization? The early EEC and the transformation of French-African relations. Freie Universität Berlin, KFG Working Paper Series 27 (http://userpage.fu-berlin.de/kfgeu/ kfgwp/wpseries/WorkingPaperKFG_27.pdf).

99. On this subject see also N. Karagiannis (2004) Avoiding Responsibility: The Politics and Discourse of European Development Policy (London: Pluto Press), esp. pp. 23-45.

100. E. Jones and C. Weinhardt (2015) Echoes of colonialism in trade negotiations between the European Union and African, Caribbean and Pacific Countries. In: K. Nicolaïdes, B. Sèbe and G. Maas (Eds), Echoes of Empire: Memory, Identity and Colonial Legacies (New York: I.B. Taurus), pp. 226-250; M. Listner (1988) The European Community and the Developing World(Aldershot: Avebury), p. 215.

101. L. Drieghe and J. Orbie (2009) Revolution in times of Eurosclerosis: the case of the first Lomé Convention. L'Europe en Formation, 3, pp. 353-354, 167-181; V. Dimier (2014) The Invention of a European Development Aid Bureaucracy: Recycling Empire (Basingstoke: Palgrave Macmillan), pp. 80-115. See also M. Holland and M. Doidge (2012) Development Policy of the European Union (Basingstoke: Palgrave Macmillan), pp. $53 \mathrm{ff}$.

102. G. Migani (2008) La France et l'Afrique sub-saharienne, 1957-1963. Histoire d'une decolonization entre idéaux eurafricains et politique de puissance (Brussels: PIE Peter Lang), p. 259. V. Dimier (2014) The Invention of a European Development Aid Bureaucracy: Recycling Empire (Basingstoke: Palgrave Macmillan), pp. $99 \mathrm{ff}$.

103. See L.A. Nichter (2015) Richard Nixon and Europe: The Reshaping of the Postwar Atlantic World (New York: Cambridge University Press), for an assessment of American foreign policy on the reshaping of Europe, as well as A. Varsori and 
G. Migani (Eds), (2011) Europe in the International Arena in the 1970s: Entering a Different World (Brussels: PIE-Peter Lang), especially L. Tosi, Europe, the United Nations and dialogue with the Third World, pp. 161-191.

104. W. Schmale (2011) Before self-reflexivity: imperialism and colonialism in the early discourse of European integration. In: M. Spiering and M. Wintle (Eds), European Identity and the Second World War (Basingstoke: Palgrave Macmillan), pp. 186-201.

105. Declaration on European Identity (Copenhagen, 14 December 1973) Bulletin of the European Communities, 12, pp. 118-122. Cf. W. Schmale (2008) Geschichte und Zukunft der Europäischen Identität (Stuttgart: Kohlhammer), pp. 121-126; A.E. Gfelle (2012), Building a European Identity. France, the United States, and the Oil Shock, 1973-74 (Oxford: Berghahn); P. Chassaigne (2011) Identité et conscience européenne: l'émergence d'un débat inachevé. Le Sommet de Copenhague, 14-15 décembre 1973. In: A. Varsori and G. Migani (Eds), Europe in the International Arena in the 1970s: Entering a Different World (Brussels: PIE-Peter Lang), pp. 243-251. On the colonial/imperial background of the concept of civilization see B. Bowden (2009) The Empire of Civilization: The Evolution of an Imperial Idea (Chicago: University of Chicago Press).

106. J. Vandamme (1987) The Tindemans Report (1975-76). In: R. Pryce (Ed.), The Dynamics of European Union (London: Routledge), p. 152.

107. Bedenkingen over de Europese Unie (KADOC, Leuven, Archives Leo Tindemans (henceforth ALT), 595).

108. Conseil des communes d'Europe, Section Italienne du CCE, 'Le Combat pour l'union européenne. Résolution politique générale' (ALT 602).

109. Notulen buitengewone vergadering, 8 juli 1975; Nederlandse kabinetsraad, September 1975 (ALT 597). On Dutch policy see R. De Bruin (2014) Elastisch Europa. De integratie van Europa en de Nederlandse politiek, 1947-1968 (Amsterdam: Wereldbibliotheek), pp. 207 ff.; A.G. Harryvan and J. van der Horst (2005) A Bumpy road to Lomé. The Netherlands, Association and the Yaounde Treaties 1956-1969. In: M.-T. Bitsch and G. Bossuat (Eds), L'Europe unie et l'Afrique: De l'idée d'Eurafrique à la Convention de Lomé 1 (Brussels: Bruylandt), pp. 319-343. On the changing meaning of the term 'Third World' with regard to Europe see the penetrating assessment of E. Tängerstad (2000) 'The Third World' as an element in the collective construction of a post-colonial European identity. In: B. Stråth (Ed.), Europe and the Other and Europe as the Other (Brussels: PIE Peter Lang, 2000), pp. 157-193.

110. Discours, ALT, 598.

111. Les solutions alternatives pour les pays européens, 4 March 1975 (ALT 614).

112. Speech François-Xavier Ortoli, European Parliament, Strasbourg, 18 February 1975 and De Cerexhe, Pourquoi l'Europe?, 17 July 1975 (ALT 614).

113. A. Williams (2004) EU Human Rights: A Study in Irony (Oxford: Oxford University Press), pp. 25-34 (and ff.).

114. See especially B. Stråth (2002) A European identity: to the historical limits of a concept. European Journal of Social Theory, 5(4), pp. 387-401.

115. Official Journal of the European Communities No 169, 29 June 1987, preamble.

116. M.R. Madsen (2016) The challenging authority of the European Court of Human Rights: from Cold War legal diplomacy to the Brighton Declaration and backlash. Law and Contemporary Problems, 79(1), pp. 141-178 and E.F. Defeis (2012) Human rights, the European Union, and the Treaty of Route: from Maastricht to Lisbon. Fordham International Law Journal, 35, pp. 1207-1230 provide useful overviews of the legal development. For a broader, historical- 
critical perspective see P. Winand (2015) The European rescue of the empire or the EU as ferment of change in International relations? In: P. Winand, A. Benvenuti and M. Guderzo (Eds), The External Relations of the European Union (Brussels: PIE Peter Lang), pp. 377-397.

117. K.E. Smith (2005) Beyond the civilian power EU debate. Politique européenne, 3(17), pp. 63-82, par. 39 (www.cairn.info/revue-politique-europeenne-2005-3page-63.htm).

118. See especially M. Holland and M. Doidge (2012) Development Policy of the European Union (Basingstoke: Palgrave Macmillan), pp. 70-82.

119. E. Jones and C. Weinhardt (2015) Echoes of colonialism in trade negotiations between the European Union and African, Caribbean and Pacific Countries. In: K. Nicolaïdes, B. Sèbe and G. Maas (Eds), Echoes of Empire: Memory, Identity and Colonial Legacies (New York: I.B. Taurus)

120. R. Kagan (2003) Of Paradise and Power: America and Europe in the New World Order (New York: Random House), p. 61.

121. F. Duchêne (1973) The European Community and the uncertainties of interdependence. In: M. Kohnstamm and W. Hager (Eds), A Nation Writ Large? Foreign-Policy Problems before the European Community (London: Macmillan), pp. 1-21, p. 19. On the concept of civilian power see J. Orbie (2006) Civilian power Europe: review of the original and current debates. Cooperation and Conflict, 41(1), pp. 123-128; B. Hettne and F. Söderbaum (2005) Civilian power or soft imperialism? The EU as a global actor and the role of interregionalism. European Foreign Affairs Review, 10(4), pp. 535-552.

122. H. Sjursen (2006) What Kind of Power?. In: H. Sjursen (Ed.), What Kind of Power? European Foreign Policy in Perspective, special issue of Journal of European Public Policy, 13(2), pp. 169-181; S. Scheipers and D. Sicurelli (2008) Empowering Africa: normative power in EU-Africa relations. Journal of European Public Policy, 15(4), pp. 607-623, 609. A somewhat similar assessment to mine is in K. Nicolaïdes (2015) Southern barbarians? A postcolonial critique of EUniversalism. In: K. Nicolaïdis, B. Sèbe and G. Maas (Eds), Echoes of Empire: Memory, Identity and Colonial Legacies (New York: I.B. Taurus).

123. I. Manners (2002) Normative power Europe: a contradiction in terms? Journal of Common Market Studies, 40(2), pp. 235-258. I. Manners (2011) The European Union's normative power: critical perspectives and perspectives on the critical. In: R.G. Whitman (Ed.), Normative Power Europe: Empirical and Theoretical Perspectives (Basingstoke: Palgrave), pp. 226-277. Manners acknowledges the 'civilizationalist' character of the concept. See also N.F. Onar and K. Nicolaïdis (2013) The decentring agenda: Europe as a postcolonial power. Cooperation and Conflict, 48(2), pp. 283-303, 284.

124. I. Manners (2002) Normative power Europe: a contradiction in terms? Journal of Common Market Studies, 40(2), p. 242.

125. https://www.youtube.com/watch?v=-I8M1T-GgRU. See P. Winand (2015) The European rescue of the empire or the EU as ferment of change in International relations? In: P. Winand, A. Benvenuti and M. Guderzo (Eds), The External Relations of the European Union (Brussels: PIE Peter Lang), pp. 380-381.

126. J. Habermas quoted and criticized in N. Maldonado-Torres (2008) Secularism and religion in the modern/colonial world system: from secular postcoloniality to postsecular transmodernity. In: M. Moraña, E. Dussel and C. Jáuregui (Eds), Coloniality at Large: Latin America and the Postcolonial Debate (Durham: Duke University Press), pp. 372-373; B. Hettne and F. Söderbaum (2005) 
Civilian power or soft imperialism? The EU as a global actor and the role of interregionalism. European Foreign Affairs Review, 10(4), pp. 535-552; and M.J. Heffernan (1989) The Meaning of Europe. Geography and Geopolitics (London: Arnold), p. 242.

127. R. Rosecrance (1998) The European Union: a new type of international actor. In: J. Zielonka (Ed.), Paradoxes of European Foreign Policy (The Hague: Kluwer), pp. 15-23, p. 22.

128. B. Hettne and F. Söderbaum (2005) Civilian power or soft imperialism? The EU as a global actor and the role of interregionalism. European Foreign Affairs Review, 10(4), p. 539. H. Haukkala (2008) The European Union as a regional normative hegemon: the case of European neighbourhood policy. Europe-Asia Studies, 60(9), pp. 1601-1622. See also K. Nicolaïdis (2015) Southern barbarians? A post-colonial critique of EUniversalism. In: K. Nicolaïdis, B. Sèbe and G. Maas (Eds), Echoes of Empire: Memory, Identity and Colonial Legacies (New York: I.B. Taurus), pp. 283-303.

129. T. Diez (2005) Constructing the self and changing others: reconsidering 'normative power Europe. Millennium, Journal of International Studies, 33, pp. 613-636.

130. José-Manuel Barroso, President of the European Commission, speech at the opening of the exhibition 'Europe meets the World', The National Museum of Denmark), 12 January 2012 (http://europa.eu/rapid/press-release_SPEECH-127_en.htm). Thanks to Koen Vandenweyer for directing my attention to this speech.

131. Cf. G.K. Bhambra (2010) Postcolonial Europe: or, understanding Europe in times of the postcolonial. In: C. Rumford (Ed.), The Sage Handbook of European Studies (London: Sage), pp. 69-85; P. Pasture (2015) Formations of European modernity. cosmopolitanism, Eurocentrism and the uses of history. International Journal for History, Culture and Modernity, 3(1), pp. 73-90.

132. H. Porsdam (2011) Human rights and European identity since World War II: Vergangenheitsbewältigung through Law. In: M. Spiering and M. Wintle (Eds), European Identity and the Second World War (Basingstoke: Palgrave Macmillan), pp. 21-36.

133. B. Forchtner and C. Kølvraa (2012) Narrating a 'new Europe': from 'bitter past' to self-righteousness? Discourse \& Society, 23(4), pp. 377-400. See also U. Beck and E. Grande (2005) Cosmopolitan Europe (Cambridge: Cambridge University Press), pp. 258-260.

134. Romano Prodi cited in P. Hansen (2004) In the name of Europe. Race \& Class, 45(3), pp. 49-61, 58.

135. Quoted in S.-L. Hoffmann (2016) Human rights and history. Past and Present, 232, p. 306.

136. For some reflections and observations see G. Garavini (2012) After Empires: European Integration, Decolonization and the Challenge from the Global South 1957-1986 (Oxford: Oxford University Press), pp. 17-19.

137. K.A. Appiah (2016) unpublished lecture: Challenges of Identity, KU Leuven, 23 November 2016.

138. S. Ghervas (2014) Antidotes to empire: from the Congress System to the European Union. In: J.W. Boyer and B. Molden (Eds), EUtROPEs: The Paradox of European Empire (Chicago: University of Chicago Press), pp. 49-81, compares the EU to a 'club of great powers' reminiscent of the Congress System after the Congress of Vienna (1815). Ghervas does not take in to account the imperialcolonial dimensions though. 


\section{About the Author}

Patrick Pasture is Professor of European and Global History and Director of the master programme in European Studies: Transnational and Global Perspectives at KU Leuven. His research mainly deals with the long-term history of Christendom and European history in a global and postcolonial perspective. He recently published Imagining European Unity since 1000 with Palgrave-Macmillan, and is currently working on a new book tentatively entitled Varieties of Christendom: Church, State and Religious Freedom in the West since 1500. 